Florida International University FIU Digital Commons

$7-1-2010$

\title{
Differences in the Susceptibility to Black Band Disease between Two Species of the Genus Diploria on the Reefs of Bermuda
}

Kristin Kuehl

Florida International University, kuehlk22@gmail.com

DOI: $10.25148 /$ etd.FI10080403

Follow this and additional works at: https://digitalcommons.fiu.edu/etd

\section{Recommended Citation}

Kuehl, Kristin, "Differences in the Susceptibility to Black Band Disease between Two Species of the Genus Diploria on the Reefs of Bermuda" (2010). FIU Electronic Theses and Dissertations. 230.

https://digitalcommons.fiu.edu/etd/230 


\title{
FLORIDA INTERNATIONAL UNIVERSITY
}

\author{
Miami, Florida
}

\section{DIFFERENCES IN THE SUSCEPTIBILITY TO BLACK BAND DISEASE BETWEEN}

TWO SPECIES OF THE GENUS DIPLORIA ON THE REEFS OF BERMUDA

A thesis submitted in partial fulfillment of the

requirements for the degree of

MASTER OF SCIENCE

in

BIOLOGY

by

Kristin Kuehl

2010 
To: Dean Kenneth Furton

College of Arts and Sciences

This thesis, written by Kristin Kuehl, and entitled Differences in the Susceptibility to Black Band Disease between Two Species of the Genus Diploria on the Reefs of Bermuda, having been approved in respect to style and intellectual content, is referred to you for judgment.

We have read this thesis and recommend that it be approved.

$\begin{array}{r}\text { Charles Bigger } \\ \hline \text { DeEtta Mills } \\ \hline \text { Laurie L. Richardson, Major Professor }\end{array}$

Date of Defense: July 1, 2010

The thesis of Kristin Kuehl is approved.

\begin{tabular}{r}
$\begin{array}{r}\text { Dean Kenneth Furton } \\
\text { College of Arts and Sciences }\end{array}$ \\
\hline Interim Dean Kevin O'Shea \\
University Graduate School
\end{tabular}

Florida International University, 2010 


\section{ABSTRACT OF THE THESIS}

DIFFERENCES IN THE SUSCEPTIBILITY TO BLACK BAND DISEASE BETWEEN

TWO SPECIES OF THE GENUS DIPLORIA ON THE REEFS OF BERMUDA

by

Kristin Kuehl

Florida International University, 2010

Miami, Florida

Professor Laurie L. Richardson, Major Professor

On the reefs of Bermuda, the coral Diploria labyrinthiformis is rarely infected with black band disease (BBD) while BBD-infected colonies of $D$. strigosa are common. This study investigated several possible explanations for the documented difference in BBD prevalence including: 1) temperature and light conditions differentially affect the progression of the disease among these two species; 2) the bacterial communities associated with each species are different and 3) the bacterial composition of BBD in Bermuda is unique from that of other geographical regions where D. labyrinthiformis has been reported with BBD. Results suggest that light and temperature are important variables in determining $\mathrm{BBD}$ progression for both species; reef location, rather than coral species dictates the coral associated bacterial diversity; and the BBD bacterial mat in Bermuda is unique compared to other regions of the Caribbean. Many factors are likely responsible for the low occurrence of BBD among D. labyrinthiformis in Bermuda. 


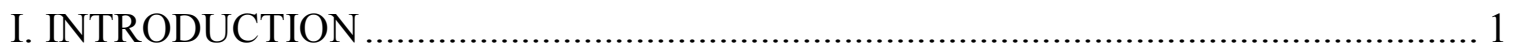

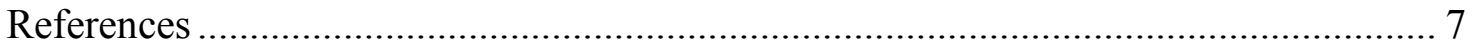

II. THE ROLES OF TEMPERATURE AND LIGHT IN BLACK BAND DISEASE (BBD) PROGRESSION ON CORALS OF THE GENUS DIPLORIA IN

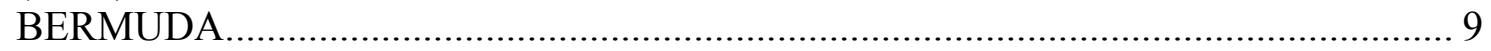

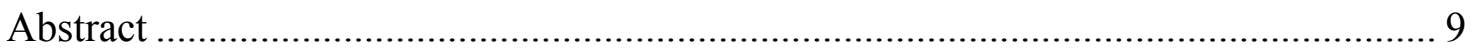

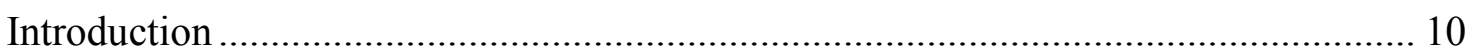



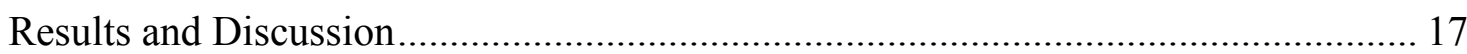

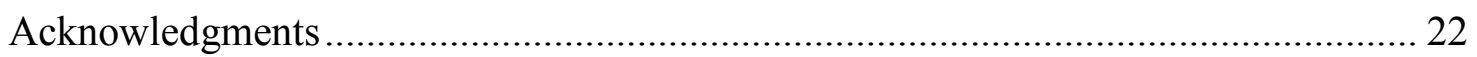



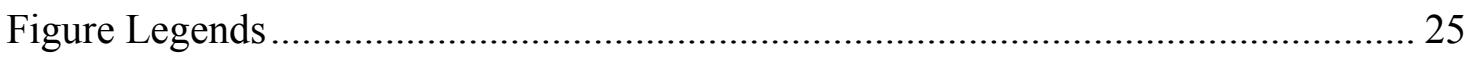

III. MICROBIAL COMMUNITIES ASSOCIATED WITH THE SURFACE MUCOPOLYSACCHARIDE LAYER OF HEALTHY AND BLACK BAND DISEASED COLONIES OF DIPLORIA IN BERMUDA ………............................. 28

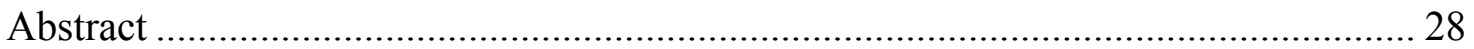

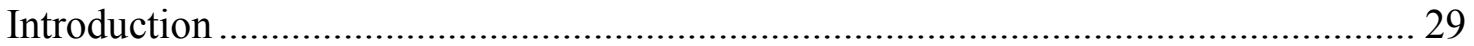

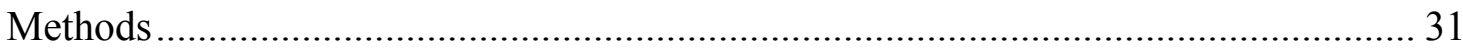





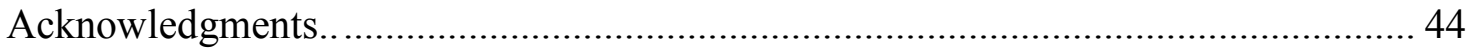

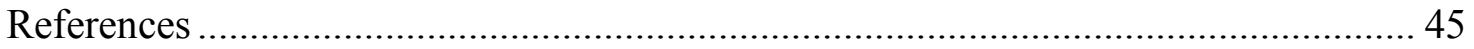

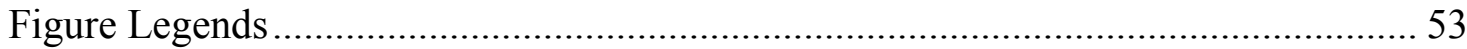

IV. A COMPARISON OF THE BACTERIAL COMPOSITION OF BLACK BAND DISEASE IN BERMUDA TO THREE REGIONS IN THE CARIBBEAN ................... 61





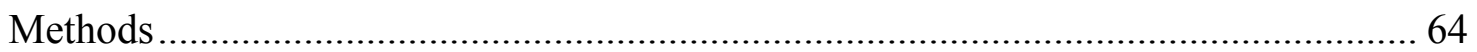

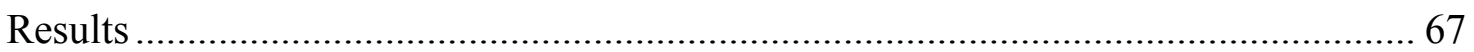




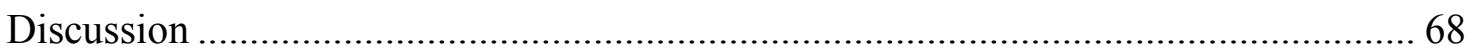

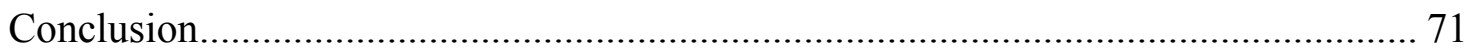

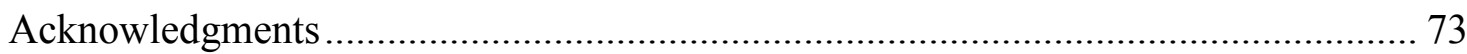

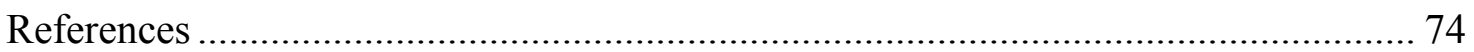



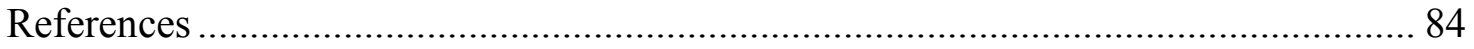

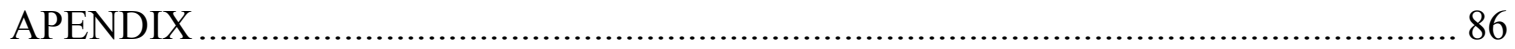




\section{LIST OF TABLES}

TABLE

PAGE

\section{CHAPTER III}

Table 1. Amplicons specific to the SML of healthy corals of each species and specific to sampling location.......................................................... 48

Table 2. SIMPER analysis of variation between SML community profiles of healthy corals between locations.

Table 3. Amplicons specific to the SML of healthy colonies and the SML of BBDinfected colonies

Table 4. SIMPER analysis of variation between the SML of healthy and BBDinfected colonies

Table 5. Summary of ANOSIM analysis of LH-PCR profiles compared by coral species, sampling location and coral health status

\section{CHAPTER IV}

Table 1. Amplicons associated with one or more BBD samples in Bermuda. .77

Table 2. Amplicons in BBD samples specific to Bermuda, absent in Bermuda, and common to Bermuda and other Caribbean regions.

Table 3. Amplicon lengths of cyanobacteria cultured from BBD in the wider

Caribbean. 


\section{LIST OF FIGURES}

FIGURE

PAGE

\section{CHAPTER I}

Figure 1. Progression of BBD across a colony of $D$. strigosa in Bermuda.............. 2

Figure 2. Marine Environmental Program (MEP) ecological monitoring sites............. 3

\section{CHAPTER II}

Figure 1. Field observations of black band disease (BBD) on reefs of Bermuda.........26

Figure 2. Black band disease (BBD) progression on experimentally infected colonies presented as calculated mean area of BBD lesions.

\section{CHAPTER III}

Figure 1. Bermuda sampling locations.

Figure 2. LH-PCR profiles of microbial communities associated with the SML of healthy colonies of Diploria labyrinthiformis and Diploria strigosa at Hog Breaker Reef and Whalebone Bay

Figure 3. LH-PCR profiles of the SML of healthy colonies and the SML of healthy areas of black band diseased colonies of Diploria labyrinthiformis and Diploria strigosa at Whalebone Bay....

Figure 4. LH-PCR profiles of the SML of healthy colonies and the SML of healthy areas of black band diseased colonies of Diploria strigosa at Hog Breaker Reef... .58 
Figure 5. Non-metric multidimensional scaling (NMDS) of amplicons................59

\section{CHAPTER IV}

Figure 1. Mean abundance of amplicons (+SE) present in BBD sampled from nine BBD-infected colonies of $D$. strigosa at Whalebone Bay, Bermuda 


\section{CHAPTER I}

\section{INTRODUCTION}

Coral reefs are among the most biologically diverse ecosystems on the planet. They support millions of species, generate billions of dollars each year within the fishing and tourism industries and protect coastlines from wave erosion (Hughes, 1994). Despite their ecological and economic importance, coral reefs are rapidly declining. Nearly one third of the worlds reefs have already been lost with another $16 \%$ considered to be at serious risk (Wilkinson, 2002). Coral disease has been implicated as one of the leading factors in the ongoing decline of reef ecosystems (Weil, 2004). Increases in coral disease incidence, geographic distribution and host species range have occurred since the 1970s (Ward and Lafferty, 2004). At present, 150 coral species worldwide are known to be affected by one or more of the 18 documented diseases (Sutherland et al., 2004).

Black band disease (BBD) is among the most ecologically important of all the coral diseases because it commonly infects slow growing reef-forming species (Rützler et al., 1983, Kuta and Richardson, 1996; Weil, 2004) The disease is characterized by a horizontally migrating black band that separates apparently healthy tissue from that of recently exposed calcium carbonate coral skeleton (Antonius, 1976). The band ranges from $1 \mathrm{~mm}$ to several $\mathrm{cm}$ wide with a thickness no greater than $1 \mathrm{~mm}$ (Carlton and Richardson, 1995). Progression of the band may reach 1-2 cm per day, killing entire colonies in a matter of months (Rützler et al., 1983; Boyett et al., 2007) (Figure 1). 


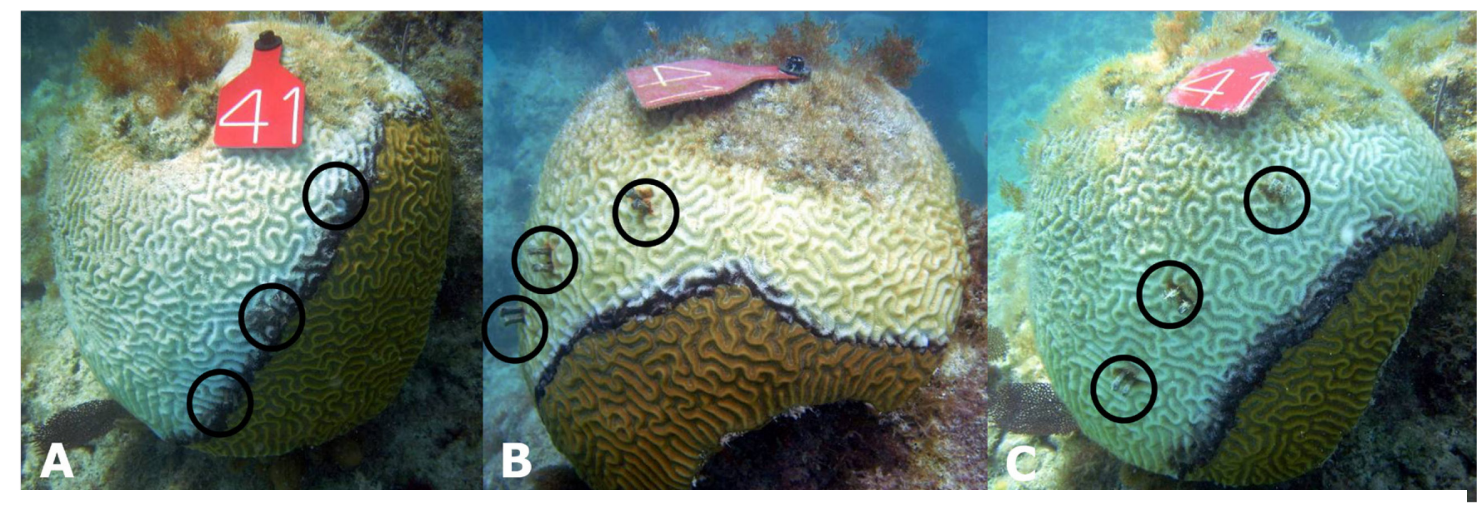

Figure 1. Progression of BBD across a colony of $D$. strigosa in Bermuda. Nails were placed adjacent to the BBD band for measurement (A); 15 days later the band had progressed $40.3 \mathrm{~mm}(\mathrm{~B})$; by day 22 the band advanced an additional $16 \mathrm{~mm}(\mathrm{C})$. (Photos provided by D. Gibbs)

In the Caribbean, species susceptible to black band disease include the large reef building corals Colpophyllia natans, the Montastrea annularis species complex, and members of the genera Siderastrea and Diploria (Sutherland et al., 2004). On the reefs of Bermuda, BBD-infected colonies of Diploria labyrinthiformis are rare whereas infected colonies of D. strigosa are common on the same reefs (Jones, 2005; 2006). Annual benthic surveys, conducted on permanent transects across the Bermuda platform (Figure 2), by the Marine Environmental Program (MEP) of the Bermuda Institute of Ocean Science (BIOS), in which I have participated, demonstrate a considerable difference in the prevalence of BBD between the two Diploria species. 


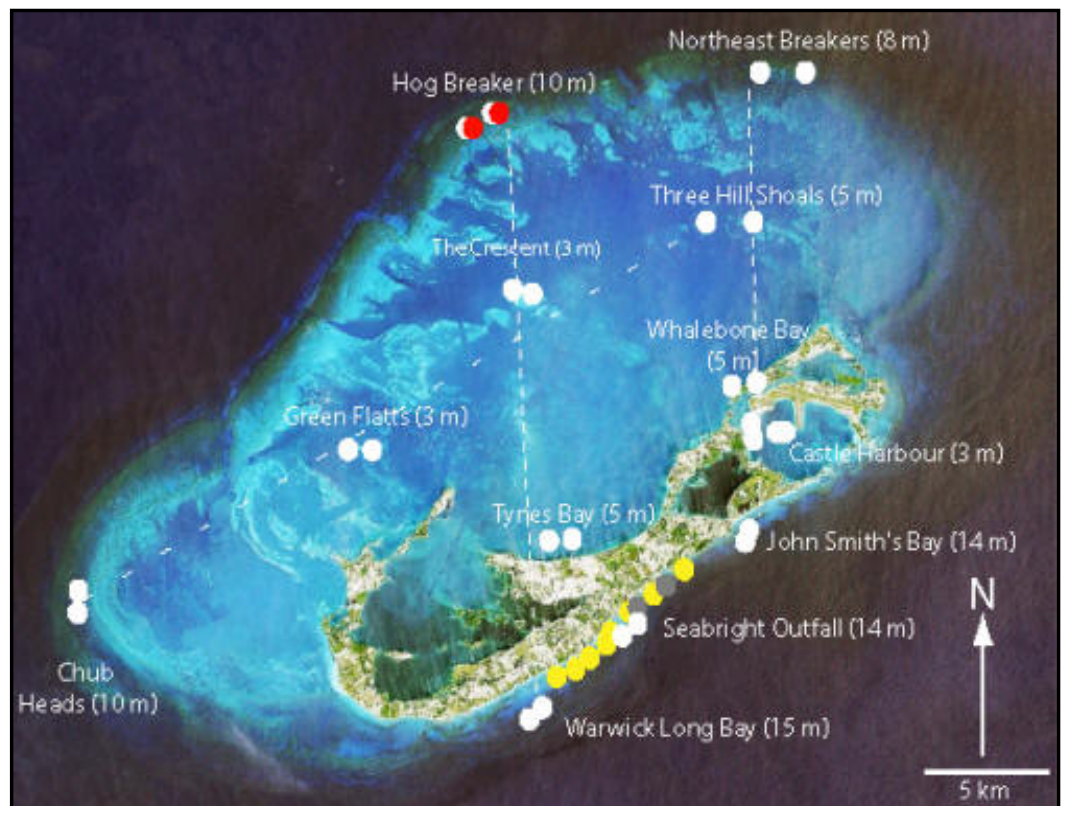

Figure 2: Marine Environmental Program (MEP) ecological monitoring sites. Map provided by R. Jones.

In 2004, 5,767 D. labyrinthiformis colonies were examined and only one had BBD (0.02\%); in 2005, no BBD was observed in the 6,798 colonies examined; only two BBD infections were noted in the 8,855 colonies examined in $2006(0.02 \%)$; and one colony out of 8,946 examined in 2007 had BBD (0.01\%). In contrast, 107 BBD infections were reported out of 12,039 D. strigosa colonies examined in 2004 (0.91\%); in 2005,89 of 15,058 had $\mathrm{BBD}(0.59 \%)$; in $2006 \mathrm{BBD}$ prevalence was $0.35 \%$ with 65 infected colonies out of 18,698 examined; and in 200740 BBD infected colonies were noted out of 17,927 examined $(0.22 \%)$ (Jones, 2005; 2006; Jones, unpublished data).

\section{Research aims, hypotheses and objectives}

The aim of the present research was to investigate the underlying reasons behind the observed difference in BBD prevalence and susceptibility between the major reef 
building corals $D$. labyrinthiformis and $D$. strigosa in Bermuda by addressing the following hypotheses:

1. Diploria labyrinthiformis is less vulnerable than D. strigosa to environmental conditions that may weaken host defenses.

2. The resident microbial community present in the surface mucopolysaccharide layer (SML) of $D$. labyrinthiformis differs from that associated with $D$. strigosa and confers resistance to BBD.

3. The bacterial composition of BBD in Bermuda differs from that of BBD in other regions of the Caribbean where BBD-infected colonies of $D$. labyrinthiformis have been reported.

One objective of the present research was to study the effect of light and temperature on the progression of BBD on both D. strigosa and D. labyrinthiformis. Chapter one details a study in which healthy colonies of both species were artificially infected with BBD under the following experimental treatments: 1) $26^{\circ} \mathrm{C}$, ambient light; 2) $30^{\circ} \mathrm{C}$, ambient light; 3) $30^{\circ} \mathrm{C}$, low light; and 4) $30^{\circ} \mathrm{C}$, high light. The progression of the disease was measured and compared between the two species to determine whether temperature and/or light availability differentially affect $\mathrm{BBD}$ progression on these two species.

A second objective of this research is described in chapter two in which the bacterial community associated with healthy and BBD-infected colonies of $D$. strigosa and D. labyrinthiformis was characterized. Recent attention has focused on the role of 
species specific microorganisms, present in the coral surface mucopolysaccharide layer (SML), as potentially providing protection against invading pathogens (Ritchie, 2006). Therefore, the bacterial communities present in the SML of healthy corals and healthy areas of BBD-infected colonies of D. labyrinthiformis and D. strigosa were characterized by amplicon length heterogeneity (LH-PCR) molecular profiling. Length heterogeneity PCR is a method that measures the lengths of the hypervariable domains of the 16S rRNA genes to distinguish microbial community patterns (Suzuki et al., 1998). Samples were collected from two reef locations: Hog Breaker Reef, an outer rim reef with minimal human impact, and Whalebone Bay, an inshore patch reef. Profiles were compared between species, locations and health status (i.e., healthy vs. diseased).

The final chapter of this thesis covers the third objective which was to characterize the bacterial composition of BBD in Bermuda and compare it to BBD collected from other regions of the Caribbean. The BBD microbial mat was collected from several colonies of $D$. strigosa in Bermuda and characterized by LH-PCR. The Bermuda BBD profiles were compared to previously published profiles by Voss and colleagues (2007), of BBD collected from the Bahamas, U.S. Virgin Islands, and the Florida Keys.

The unique pattern of BBD infections in Bermuda provides an opportunity to examine the role of environmental variables in disease progression and to compare defense mechanisms of disease susceptible and non-susceptible coral species. 
Understanding the relationship between BBD pathogen(s) and species of the host genus Diploria is particularly important in Bermuda where these species comprise the major reef infrastructure. Further, Bermudian reefs may be especially slow to recover from disease outbreaks as characteristically cold winter waters dictate the slower growth of scleractinian species at these high latitude reefs (Cook et al., 1993). 


\section{REFERENCES}

Antonius, A., 1976. New observations on coral destruction in reefs. $10^{\text {th }}$ Mtg. Assoc. of Is. Mar. Lab. Car. Abst. 3.

Boyett, H., Bourne, D.G., Willis, B., 2007. Elevated temperature and light enhance progression of black band disease on staghorn corals of the Great Barrier Reef. Mar. Biol. 151, 1711-1720.

Carlton, R. G., Richardson, L.L., 1995. Oxygen and sulfide dynamics in a horizontally migrating cyanobacterial mat - black band disease of corals. FEMS Microbiol.

Ecol. 18, 155-162.

Cook, C.B., Logan, A., Ward, J., Luckhurst, B., Berg, C.J., 1990. Elevated temperatures and bleaching on a high latitude coral reef: the 1988 Bermuda event. Coral Reefs 9, 45-49.

Hughes, T.P., 1994. Catastrophes, phase shifts, and large-scale degradation of a Caribbean coral reef. Science 265, 1547-1551

Jones, R.J., 2005. Bermuda Biological Station for Research (BBSR), Marine Environmental Program (MEP) Annual report (2004-2005), submitted to the Bermuda Government Department of Environmental Protection, Ministry of the Environment.

Jones, R.J., 2006. Bermuda Institute of Ocean Sciences (BIOS), Marine Environmental Program (MEP) Annual report (2005-2006), submitted to the Bermuda Government Department of Environmental Protection, Ministry of the Environment.

Kuta, K.G., Richardson, L.L., 1996. Abundance and distribution of black band disease on coral reefs in the northern Florida Keys. Coral Reefs 15, 219-223.

Ritchie, K.B., 2006. Regulation of microbial populations by coral surface mucus and mucus-associated bacteria. Mar. Ecol. Prog. Ser. 322, 1-14.

Rützler, K., Santavy, D.L., Antonius, A., 1983. The black band disease of Atlantic reef corals. III. Distribution, ecology, and development. PSZN I: Mar. Ecol. 4, 329358.

Sutherland, K., Porter, J.W., Torres, C., 2004. Disease and immunity in Caribbean and Indo-Pacific zooxanthellate corals. Mar. Ecol. Prog. Ser. 266, 273-302. 
Suzuki, M., Rappe, M.S., Giovannoni, S.J., 1998. Kinetic bias in estimates of coastal picoplankton community structure obtained by measurements of small-subunit rRNA gene PCR amplicon length heterogeneity. Appl. Environ. Microbiol. 64, 4522-4529.

Voss, J. D., Mills, D.K, Myers, J.L, Remily, E.R., Richardson, L.L., 2007. Black band disease microbial community variation on corals in three regions of the wider Caribbean. Microb. Ecol. 54, 730-739.

Ward, J.R., Lafferty, K.D., 2004. The elusive baseline of marine disease: are diseases in ocean ecosystems increasing? PLoS Biol 2:E120.

Weil, E., Coral reef diseases in the Wider Caribbean. In: E. R. a. Y. Loya, (Ed.), Coral Health and Disease. Springer-Verlag, Berlin, 2004, pp. p. 35-68.

Wilkinson, C., 2002. Status of coral reefs of the world, Australian Institute of Marine Science, Townsville. 


\title{
CHAPTER II
}

\section{THE ROLES OF TEMPERATURE AND LIGHT IN BLACK BAND DISEASE (BBD) PROGRESSION ON CORALS OF THE GENUS DIPLORIA IN BERMUDA}

\begin{abstract}
On Bermuda reefs the coral Diploria labyrinthiformis is rarely documented with black band disease (BBD), while BBD-affected colonies of D. strigosa are common. Diploria labyrinthiformis on these reefs may be more resistant to BBD or less affected by prevailing environmental conditions that potentially diminish host defenses. Temperature and light are known to influence the incidence and progression of BBD. Infection experiments were conducted under the following experimental treatments: 1) $26^{\circ} \mathrm{C}$, ambient light; 2) $30^{\circ} \mathrm{C}$, ambient light; 3) $30^{\circ} \mathrm{C}$, low light; and 4) $30^{\circ} \mathrm{C}$, high light, to determine whether light and/or temperature affect BBD progression differently on these two species. Disease progression was slower at $26^{\circ} \mathrm{C}$ than at $30^{\circ} \mathrm{C}$ on both species at ambient light. Low light at $30^{\circ} \mathrm{C}$ counteracted the effect of elevated temperature on $\mathrm{BBD}$ lesion size for both species. High light at $30^{\circ} \mathrm{C}$ resulted in elevated BBD progression on colonies of $D$. strigosa and reduced progression on colonies of $D$. labyrinthiformis. The final affected area of BBD was significantly greater on colonies of D. labyrinthiformis in the $30^{\circ} \mathrm{C}$ ambient light treatment than in each of the other treatments. The area of the BBD lesions were significantly less on D. strigosa colonies in the $30^{\circ} \mathrm{C}$ low light treatment than on colonies at the same temperature with ambient
\end{abstract}


light. These results suggest that light and temperature are important factors regulating BBD progression on both species of Diploria in Bermuda.

\section{INTRODUCTION}

Black band disease (BBD) is a polymicrobial disease that affects corals. It is considered a serious threat to coral reef health as it commonly affects slow-growing, reef-framework species, particularly in the wider Caribbean (Weil, 2004). The microbial community associated with BBD is dominated by phycoerythrin-rich, filamentous, gliding cyanobacteria and includes diverse members of heterotrophic and sulfur cycle bacteria (Richardson, 2004). It appears as a black band that lyses coral tissue as it progresses across an infected colony at rates between $3 \mathrm{~mm}$ to $>2 \mathrm{~cm}$ per day, and can completely kill a host colony in a matter of months (Rützler et al., 1983; Boyett et al., 2007). While the complete etiology of the disease is still not known, at least two toxic substances, sulfide and cyanotoxin, are produced by BBD microorganisms and have been shown to deleteriously affect the coral host (Richardson et al., 2009).

Black band disease is known to infect 64 species of scleractinian corals, 19 of which are found in the Caribbean (Sutherland et al., 2004). Susceptible species include the most important reef-forming corals, which in the wider Caribbean are the Montastraea species complex, Colpophyllia natans, and members of the genera Siderastrea and Diploria (Sutherland et al., 2004). Typical prevalence values among infected host populations are $<1 \%$ (Edmunds, 1991). 
On reefs of Bermuda there is a distinct difference in the susceptibility to BBD of the two major reef-building host species, Diploria strigosa and D. labyrinthiformis (Jones, 2006). There are reports of BBD infecting these two species throughout the wider Caribbean, albeit with $D$. strigosa more frequently reported to be affected (Edmunds, 1991; Green and Bruckner, 2000; Kaczmarsky et al., 2005; Voss et al., 2007). However, on reefs of Bermuda BBD-affected D. strigosa colonies are commonly observed while affected $D$. labyrinthiformis colonies are extremely rare (Rützler et al., 1983; Jones, 2006). In fact, long term monitoring has shown that prevalence within the D. labyrinthiformis population is an order of magnitude lower than that for $D$. strigosa on the same reefs (Jones, 2006). For example, surveys in 2007 revealed that of 17,927 D. strigosa colonies examined, $40(0.22 \%)$ had BBD, while only one of $8,946(0.01 \%)$ D. labyrinthiformis colonies was infected (Jones, unpublished data).

Diploria strigosa is the more abundant of the two species in Bermuda, with approximately twice the number of colonies as D. labyrinthiformis. Clusters of BBD infected $D$. strigosa colonies are commonly observed (Fig.1A) suggesting that the disease is highly infectious between colonies. It has, in fact, been previously shown that BBD infected corals have a clumped distribution (Bruckner and Bruckner, 1997; Kuta and Richardson, 1996). The much lower prevalence of BBD on D. labyrinthiformis could conceivably be the result of differences in host density - however, BBD infected D. strigosa colonies can be found directly adjacent to, including touching, healthy $D$. labyrinthiformis colonies (Fig. 1B) indicating that there may be a true difference in disease susceptibility. 
There are several other potential explanations for the differences in BBD prevalence between the two species. It may be that D. labyrinthiformis in Bermuda possess greater innate resistance to the BBD pathogen(s) such as a greater ability to remove foreign matter (including potential pathogens) from the coral surface. Colonies of this species may be less vulnerable than $D$. strigosa to environmental conditions that weaken host defenses. Some environmental conditions are known to influence the incidence and severity of BBD. These include temperature, light, and nutrients (Kuta and Richardson, 2002; Rodriguez and Croquer, 2008; Voss and Richardson, 2006a). Infections of BBD are largely seasonal, with the highest prevalence and the fastest disease progression rates occurring when water temperature is at or above $28^{\circ} \mathrm{C}$ (Rützler et al., 1983; Edmunds, 1991; Voss and Richardson, 2006b; Boyett et al., 2007; Sato et al., 2009). Additionally, sites with a high prevalence of BBD are normally shallow, presumably as a result of light limitation at depth (Kuta and Richardson, 1996; Bruckner and Bruckner, 1997). Addition of nutrients has been shown to increase BBD disease progression in situ (Voss and Richardson, 2006a). One study in the Caribbean showed that the presence of elevated nutrients can counteract the effect of temperature (Rodriguez and Croquer, 2008), and in situ field observations and manipulative aquaria experiments in the Great Barrier Reef have shown that conditions of elevated water temperature in combination with elevated irradiance may act synergistically to enhance BBD progression (Boyett et al., 2007). The same study also suggested that low light can mitigate the effect of high water temperatures on BBD progression. The results of all of these studies suggest that environmental factors are important in controlling BBD, and that many complex interactions are involved. In the present study, colonies of $D$. 
strigosa and $D$. labyrinthiformis were artificially infected with BBD under various light and temperature regimes to determine whether these environmental conditions differentially affect the progression of the disease on these two species.

\section{MATERIALS AND METHODS}

Sample collection

Small colonies (ca. $5 \mathrm{~cm}$ in diameter) of apparently healthy $D$. strigosa and $D$. labyrinthiformis were collected (June 26, 2008) from a northern rim reef near Hog Breaker $\left(32^{\circ} 27.55^{\prime} \mathrm{N}, 64^{\circ} 49.89^{\prime} \mathrm{W}\right)$, a location chosen for its high density of corals in this size class. Colonies, collected using SCUBA at depths of 7.6 to $8.8 \mathrm{~m}$ by the use of a hammer and chisel, were individually placed in clean plastic bags filled with ambient seawater. Upon surfacing colonies were floated in covered containers, arranged by species, until return to the Bermuda Institute of Ocean Sciences (BIOS) field station (ca. 2 hours). Prior to infection, D. strigosa and D. labyrinthiformis colonies were maintained on opposite sides of a large holding aquarium $(99.1 \mathrm{~cm} \times 110.5 \mathrm{~cm}$ x 68.6 $\mathrm{cm}$ ) supplied with continuous flow-through seawater and covered with neutral density screen to match in situ irradiance as measured on the reef with a LI-1400 data logger (LI-COR Biosciences, Lincoln, NE, USA). Colonies were allowed to recover for at least a week before infection. No colonies exhibited signs of disease prior to infection. Control colonies were cemented back on the reef following the completion of the experiment. 
The BBD mat was collected from infected $D$. strigosa colonies on inshore patch reefs located approximately $100 \mathrm{~m}$ north of Whalebone Bay $\left(32^{\circ} 21.58^{\prime} \mathrm{N}\right.$, $\left.64^{\circ} 42.53^{\prime} \mathrm{W}\right)$. No BBD infected colonies of D. labyrinthiformis were located, however a study by Voss et al., (2007) suggests that geographic location is more important than host species in determining the BBD microbial community assemblage. The BBD was collected using sterile, needleless $10 \mathrm{ml}$ syringes, and the BBD samples to be used for infection were taken from a single band (on the day of infection) and maintained in ambient water under low light conditions until used for inoculations (ca. 2 hours).

\section{Infection experiments}

A small aliquot of BBD (ca. $\left.0.5 \mathrm{~cm}^{2}\right)$ was deposited directly on top of an artificial lesion, created by scratching the coral surface with sterile forceps, at the crown of colonies of $D$. labyrinthiformis and $D$. strigosa under four experimental treatments 1) $26{ }^{\circ} \mathrm{C}$, ambient light; 2) $30^{\circ} \mathrm{C}$, ambient light; 3) $30^{\circ} \mathrm{C}$, low light and 4) $30{ }^{\circ} \mathrm{C}$, high light. Six colonies of each species were infected in treatments \#1 and \#2 and three of each species were infected in \#3 and \#4. The sample size was chosen to accommodate the constraints of the collecting permit. Control colonies $(\mathrm{N}=2$ per species for treatments \#1 and \#2 and $\mathrm{N}=1$ per species for treatments \#3 and \#4) were similarly abraded and inoculated with seawater. The temperature measured on the reef at the time of collection was $26^{\circ} \mathrm{C}$ which served as the ambient control. The increased temperature was set at $30^{\circ} \mathrm{C}$ based on reports that $\mathrm{BBD}$ prevalence is highest on reefs of the Caribbean at and above $28^{\circ} \mathrm{C}$ (Rützler et al., 1983; Edmunds, 1991; Voss and Richardson, 2006; Boyett et al., 2007; Sato et al., 2009). Temperature was gradually 
increased, prior to infection, to $30^{\circ} \mathrm{C}$ in these aquaria by $0.5^{\circ} \mathrm{C}$ every 12 hours to allow the corals to acclimate.

For infection, each colony was individually placed within a four-liter volume container supplied with surface aeration. The containers were housed within a large water bath $(80 \mathrm{~cm} \times 45.7 \mathrm{~cm} \times 32.4 \mathrm{~cm})$ fitted with a clear polycarbonate lid to prevent influx of rain water. Three experimental colonies and one control colony for both species were haphazardly placed within each water bath. Corals were provided with fresh sea water every morning. Water temperature was maintained using Polyscience 6000 Series Chillers (Polyscience, Niles, IL, USA) outfitted with an external temperature probe and cooling coil. Temperature was logged every ten minutes for the duration of the experiment using HOBO ProV2 data loggers (Onset Computer Corp., Pocasset, MA, USA). Mean temperatures ( \pm SD) recorded were $26.0 \pm 0.7^{\circ} \mathrm{C}$ and $25.7 \pm$ $0.5^{\circ} \mathrm{C}$ for the $26^{\circ} \mathrm{C}$ ambient treatment; $29.0 \pm 0.6^{\circ} \mathrm{C}$ and $29.2 \pm 0.5^{\circ} \mathrm{C}$ for the $30^{\circ} \mathrm{C}$ ambient treatment; and $29.8 \pm 0.7^{\circ} \mathrm{C}$ and $29.5 \pm 0.7^{\circ} \mathrm{C}$ for the $30^{\circ} \mathrm{C}$ low and high light treatments respectively. Light levels within the stack nest containers were measured with a LI-250A light meter. Ambient irradiance was determined by the in situ irradiance on the reef at a depth of $10 \mathrm{~m}$. Low $\left(186 \pm 47 \mu \mathrm{mol} \mathrm{s}^{-1} \mathrm{~m}^{-2}\right)$, ambient $(608 \pm 65 \mu \mathrm{mol} \mathrm{s}$ $\left.{ }^{1} \mathrm{~m}^{-2}\right)$ and high $\left(870 \pm 88 \mu \mathrm{mol} \mathrm{s}^{-1} \mathrm{~m}^{-2}\right)$ light levels within the stack nest containers were achieved by layering neutral density screen on top of the polycarbonate lid.

A digital photograph of the affected area of each coral was taken at the same time each day for seven days. The area of the BBD lesion $\left(\mathrm{cm}^{2}\right)$ was measured using ImageJ image processing software (Abramoff et al., 2004). The "final affected area" of 
BBD on D. labyrinthiformis and D. strigosa within each treatment is defined as the area of the $\mathrm{BBD}$ lesion on day seven minus the area of the BBD inoculum. Results were compared using a Student's one-tailed $t$-test. Prior to statistical analyses, the raw data were tested for normality using the Shapiro-Wilks test and for homogeneity of variance using the F-test for variance. Data were normalized by natural log transformation and compared assuming equal or unequal variance depending on the outcome of the F-test.

\section{Sediment shedding experiment}

In order to quantify the ability of colonies of $D$. labyrinthiformis and $D$. strigosa to remove foreign matter from the coral surface, marine sediment was applied to the surface of each species. The surface area of ten small colonies each of $D$. labyrinthiformis $\left(89 \pm 26 \mathrm{~cm}^{2}\right)$ and D. strigosa $\left(89 \pm 16 \mathrm{~cm}^{2}\right)$ was determined using the aluminum foil technique (Marsh, 1970). Each colony was placed into an individual container filled with one liter of filtered seawater. Two grams (dry weight) of marine sediment, filtered through a $250 \mu \mathrm{m}$ mesh sieve, were placed directly on the surface of each colony. Each colony was removed from the container after 60 minutes of exposure to the sediment, with care not to disturb sediment that had not been removed by the coral. The remaining water and sediment were filtered under vacuum through a Whatman glass fiber filter, dried overnight at $80^{\circ} \mathrm{C}$, and weighed on an Adenturer Pro AV313 scale. The percentage of sediment cleared by each species was compared using a Student's two-tailed $t$-test. All experimental colonies were cemented back on the reef following conclusion of the experiment. 


\section{RESULTS AND DISCUSSION}

For both host species in the $26^{\circ} \mathrm{C} / \mathrm{ambient}$ light treatment $\mathrm{BBD}$ lesion growth was slow, with average increases in the lesion areas of $<1 \mathrm{~cm}^{2} /$ day (Fig. 2A). One colony of $D$. strigosa exhibited a much more virulent infection, with progression rates approaching $5 \mathrm{~cm}^{2} /$ day (shown by cross hatches in Fig. 2A). The reasons behind the accelerated $\mathrm{BBD}$ growth on this colony are unknown but compounding factors such as host stress level and individual colony history may have played a role. Elevated temperature $\left(30^{\circ} \mathrm{C}\right)$, again with ambient light, resulted in increased progression of the BBD lesions for both species (Fig. 2B). Under these conditions the lesions after the seven day experiment were approximately twice the size as those at the lower temperature. Increased lesion growth at $30^{\circ} \mathrm{C}$ may be due to an increase in the virulence of the BBD pathogen(s) at an elevated temperature. Richardson and Kuta (2003) reported optimal growth of one BBD associated cyanobacterium to occur at or above $30^{\circ} \mathrm{C}$. Elevated temperature may also facilitate BBD lesion growth because of a reduction in the host coral's ability to resist the disease under thermal stress. A general stress response in corals is "bleaching" or the loss of the coral host's symbiotic algae of the genus Symbiodinium. In Bermuda both Diploria species have been documented to exclusively harbor the same clade of Symbiodinium (Savage et al., 2002). However, the ability of each coral species to process an increase in harmful waste products that result from a temperature-related increase in metabolic activity may be different and explain variable host resistance. 
Low light (Fig. 2C) counteracted the effect of elevated temperature on BBD lesion increase for both species. Under low light conditions the lesion increased only about half the amount of the low temperature/ambient light treatment. Such results may be attributed to light requirements of the photosynthetic cyanobacteria and microflora within the BBD microbial community. Alternatively, reduced irradiance may alleviate some environmental stress on the coral host as it has been reported (Coles and Jokiel, 1978) that the ability of a coral to resist thermal stress was decreased in the presence of high light intensity. It is therefore not surprising that the combination of high light/high temperature $\left(30^{\circ} \mathrm{C}\right)$ resulted in enhanced BBD progression on D. strigosa (Fig. 2D). Reduced progression of BBD was unexpectedly observed on colonies of $D$. labyrinthiformis in this treatment (Fig. 2D). It is not clear why this occurred although it may relate to differences in the microbial communities associated with each species. It is now known that different species of corals host species-specific populations of associated bacteria (Rohwer et al., 2002). Perhaps some resident microbes unique to $D$. labyrinthiformis are favored under high light conditions and provide more resistance to the encroaching BBD mat. Alternatively, the flatter surface morphology of $D$. labyrinthiformis, characterized by broad ambulacral grooves, may expose the cyanobacteria to too much light for optimum growth.

There was no significant difference in the final affected area between D. strigosa and D. labyrinthiformis in any of the individual treatments. There were, however, significant differences within the species between treatments. The final affected area of $\mathrm{BBD}$ on D. labyrinthiformis colonies in the $26^{\circ} \mathrm{C} /$ ambient light treatment was 
significantly lower than on colonies in the $30^{\circ} \mathrm{C} /$ ambient light treatment $(\mathrm{p}=0.04 ; 1$ tailed $t$-test). In contrast, there was no significant difference between the affected area on D. strigosa colonies in the $26^{\circ} \mathrm{C}$ and $30^{\circ} \mathrm{C}$ ambient light treatments $(\mathrm{p}=0.36 ; 1$ tailed $t$-test). The role of temperature on the BBD lesion size appears to be closely linked with light levels. The final affected area was significantly less on colonies of $D$. labyrinthiformis in the $30^{\circ} \mathrm{C}$ low light treatment than in either the $26^{\circ} \mathrm{C}(\mathrm{p}=0.003 ; 1$ tailed $t$-test $)$ or $30^{\circ} \mathrm{C}(\mathrm{p}=0.01 ; 1$-tailed $t$-test $)$ ambient light treatments and on colonies of $D$. strigosa in the $30^{\circ} \mathrm{C}$ ambient light treatment ( $\mathrm{p}=0.02 ; 1$-tailed $t$-test). High light levels at $30^{\circ} \mathrm{C}$ increased the progression of $\mathrm{BBD}$ on colonies of $D$. strigosa; however the final affected area of colonies in this treatment (on day seven) was not significantly different from colonies in any of the other three treatments $\left(26^{\circ} \mathrm{C} / \mathrm{ambient}\right.$ light, $\mathrm{p}=$ $0.32 ; 30{ }^{\circ} \mathrm{C} / \mathrm{ambient}$ light, $\mathrm{p}=0.38 ; 30{ }^{\circ} \mathrm{C} /$ low light, $\mathrm{p}=0.10 ; 1$-tailed $t$-test). In contrast, the final BBD lesion area on colonies of D. labyrinthiformis in the $30^{\circ} \mathrm{C}$, high light treatment was significantly less than on colonies in the $30^{\circ} \mathrm{C}$, ambient light treatment $(\mathrm{p}=0.03 ; 1$-tailed $t$-test $)$.

Experimentally, temperature and light appear to be two important factors regulating BBD progression on colonies of $D$. strigosa and D. labyrinthiformis. These results may act as a foundation for further investigations to explain the differences in the susceptibility and resistance to BBD between these two host species in Bermuda. Temperature in particular appears to play an important role in governing BBD progression on colonies of D. labyrinthiformis as the increase in the lesion area on colonies of $D$. labyrinthiformis in the $30^{\circ} \mathrm{C} /$ ambient light treatment was significantly 
greater than colonies in any of the other treatments. Historical data indicate that surface seawater temperatures in Bermuda do not typically increase above $28^{\circ} \mathrm{C}$, although isolated temperature spikes of $30^{\circ} \mathrm{C}$ have been measured (Cook et al., 1990). In contrast, the sea surface temperatures on the lower latitude reefs of the wider Caribbean typically reach or even exceed $30^{\circ} \mathrm{C}$. Therefore, the very low susceptibility of $D$.

labyrinthiformis to BBD on the reefs of Bermuda may simply be the result of the regionally cool water temperatures.

While there were significant differences in the final BBD lesion area within species between treatments, there were not significant differences between species which suggested that other factors in addition to lower temperature and prevailing light may be contributing to the very low BBD prevalence of $D$. labyrinthiformis on the reefs of Bermuda. Factors may include the greater ability of $D$. labyrinthiformis to remove foreign matter that lands on the coral surface (such as BBD pathogens). In the sediment shedding experiment, $D$. labyrinthiformis removed significantly more sediment than $D$. strigosa, clearing $72 \pm 26 \%$ grams over a period of one hour when compared to $39 \pm$ $16 \%$ for $D$. strigosa $(\mathrm{p}=0.02,2$-tailed $t$-test). Alternatively, the effect of temperature may result from a negative impact on coral-associated bacteria that normally protect $D$. labyrinthiformis from disease (the coral probiotic hypothesis; (Reshef et al., 2006)).

The results of our laboratory experiments reveal that temperature appears to be an environmental factor worth investigating further to explain the differences in BBD susceptibility between the two major reef-building coral species on the reefs of Bermuda. If corroborated with field studies, the finding that elevated temperature results 
in the reduced ability of a coral species to resist disease has important implications in terms of global warming. Specifically, rising sea surface temperatures may result in greater prevalence of disease among currently non-susceptible species, which may be of particular concern to the marginal high latitude reefs of Bermuda. 


\section{ACKNOWLEDGMENTS}

I would like to thank J. Evered, C. Sleeter, K. Holzer and T. Noyes for field assistance. Comments provided by L. Kaczmarsky, B. Zimmer and two anonymous reviewers helped improve this manuscript. This work was funded by the Sydney L. Wright and the Samuel Riker Fellowships and by an Environmental Protection Agency Greater Research Opportunity Graduate Fellowship (MA-91697601). This chapter has been submitted for publication to the Journal of Invertebrate pathology as "Kristin Kuehl, Ross Jones, David Gibbs and Laurie Richardson. The roles of temperature and light in black band disease (BBD) progression on corals of the genus Diploria in Bermuda." 


\section{REFERENCES}

Abramoff, M. D., Magelhas, P.J., Ram, S.J., 2004. Image processing with ImageJ. Biophotonics Int. 11, 36-42.

Boyett, H.V., Bourne, D.G., Willis, B.L., 2007. Elevated temperature and light enhance progression of black band disease on staghorn corals of the Great Barrier Reef. Mar. Biol. 151, 1711-1720.

Bruckner, A., Bruckner, R., 1997. The persistence of black band disease in Jamaica: Impact on community structure. Proc. 8th Intl. Coral Reef Symp., Smithsonian Trop. Res. Inst., Panama. I, 601-606.

Coles, S., Jokiel, P., 1978. Synergistic effects of temperature, salinity, and light on the hermatypic coral Montipora verrucosa. Mar. Biol. 49, 187-195.

Cook, C.B., Logan, A., Ward, J., Luckhurst, B., Berg, C.J., 1990. Elevated temperatures and bleaching on a high latitude coral reef: the 1988 Bermuda event. Coral Reefs 9, 45-49.

Edmunds, P. J., 1991. Extent and effect of black band disease on Caribbean reefs. Coral Reefs 10, 161-165.

Green, E.P., Bruckner, A.W., 2000. The significance of coral disease epizootiology for coral reef conservation. Biol. Cons. 96, 347-361.

Jones, R.J. Bermuda Institute of Ocean Sciences (BIOS), Marine Environmental Program (MEP) Annual report (2005-2006), submitted to the Bermuda Government Department of Environmental Protection, Ministry of the Environment.

Kaczmarsky, L.T., Draud, M., Williams, E.H., 2005. Is there a relationship between proximity to sewage effluent and the prevalence of coral disease? Caribb. J. Sci. 41, 124-137.

Kuta, K. G., Richardson, L.L., 1996. Abundance and distribution of black band disease of corals in the northern Florida Keys. Coral Reefs 15, 219-223.

Kuta, K. G., Richardson, L. L., 2002. Ecological aspects of black band disease of corals: relationships between disease incidence and environmental factors. Coral Reefs 21, 393-398.

Marsh, J.A., 1970. Primary productivity of reef building calcareous red algae. Ecology $51,255-263$.

Reshef, L., Omry, K., Loya, Y., Zilber-Rosenberg, I., Rosenberg, E., 2006. The coral probiotic hypothesis. Environ. Microbiol. 8, 2068-2073. 
Richardson, L. L., Kuta, K. G., 2003. Ecological physiology of the black band disease cyanobacterium Phormidium corallyticum. FEMS Microb. Ecol. 43, 287-298.

Richardson, L. L., Black band disease. In: E. R. a. Y. Loya, (Ed.), Coral Health and Disease. Springer-Verlag, 2004, pp. 325-336.

Richardson, L. L., Miller, A.W., Broderick, E., Kaczmarsky, L., Gantar, M., Stanić, D., Sekar, R., 2009. Sulfide, microcystin, and the etiology of black band disease. Dis. Aquat. Org. 87, 79-90.

Rodriguez, S., Croquer, A., 2008. Dynamics of black band disease in a Diploria strigosa population subjected to annual upwelling on the northeastern coast of Venezuela. Coral Reefs 27, 381-388.

Rohwer, F., Seguritan, V., Azam, F., Knowlton, N., 2002. Diversity and distribution of coral-associated bacteria. Mar. Ecol. Prog. Ser. 243, 1-10.

Rützler, K., Santavy, D.L., Antonius, A., 1983. The black band disease of Atlantic reef corals. III. Distribution, Ecology and Development. PSZN I: Mar Ecol 4: 329358.

Sato, Y., Bourne, D.G., Willis, B.L., 2009. Dynamics of seasonal outbreaks of black band disease in an assemblage of Montipora species at Pelorus Island (Great Barrier Reef, Australia). Proc. R. Soc. B. 276, 2795-2803.

Savage, A.M., Goodson, M.S., Visram, S., Trapido-Rosenthal, H., Wiedenmann, J., Douglas, A.E., 2002. Molecular diversity of symbiotic algae at the latitudinal margins of their distribution: dinoflagellates of the genus Symbiodinium in corals and sea anemones. Mar. Ecol. Prog. Ser. 244, 17-26.

Sutherland, K., Porter, J.W., Torres, C., 2004. Disease and immunity in Caribbean and Indo-Pacific zooxanthellate corals. Mar. Ecol. Prog. Ser. 266, 273-302.

Voss, J., Richardson, L.L, 2006a. Nutrient enrichment enhances black band disease progression in corals. Coral Reefs 25, 569-576.

Voss, J., Richardson, L.L, 2006b. Coral diseases near Lee Stocking Island, Bahamas: patterns and potential drivers. Dis. Aquat. Org. 69, 33-40.

Voss, J. D., Mills, D.K, Myers, J.L, Remily, E.R., Richardson, L.L., 2007. Black band disease microbial community variation on corals in three regions of the wider Caribbean. Microb. Ecol. 54, 730-739.

Weil, E., Coral reef diseases in the Wider Caribbean. In: E. R. a. Y. Loya, (Ed.), Coral Health and Disease. Springer-Verlag, Berlin, 2004, pp. p. 35-68. 


\section{FIGURE LEGENDS}

Figure 1. Field observations of black band disease (BBD) on reefs of Bermuda. (A) Four neighboring Diploria strigosa colonies with BBD and (B) BBD-infected $D$. strigosa touching a healthy colony of $D$. labyrinthiformis.

Figure 2. Black band disease (BBD) progression on experimentally infected colonies presented as calculated mean area of BBD lesions. Experimental conditions: (A) $26^{\circ} \mathrm{C}$, ambient light (includes a single colony outlier of $D$. strigosa, indicated by cross hatches); (B) $30^{\circ} \mathrm{C}$, ambient light; (C) $30^{\circ} \mathrm{C}$, low light; (D) $30^{\circ} \mathrm{C}$, high light. For reference, the $30^{\circ} \mathrm{C}$, ambient light treatment is shown in grey on panels (C) and (D).

Errors bars are $\pm \mathrm{SE}$. 


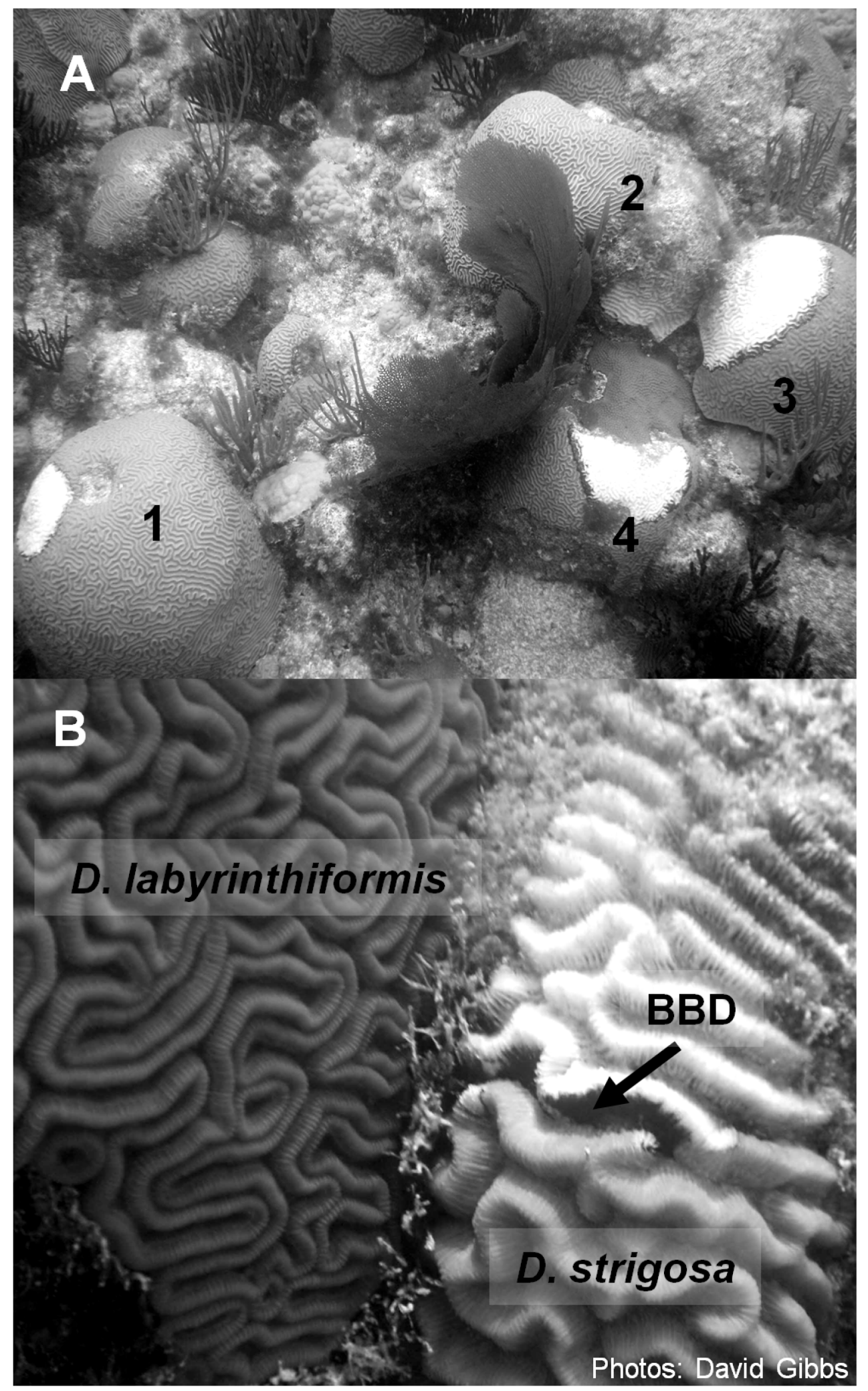

Figure 1 


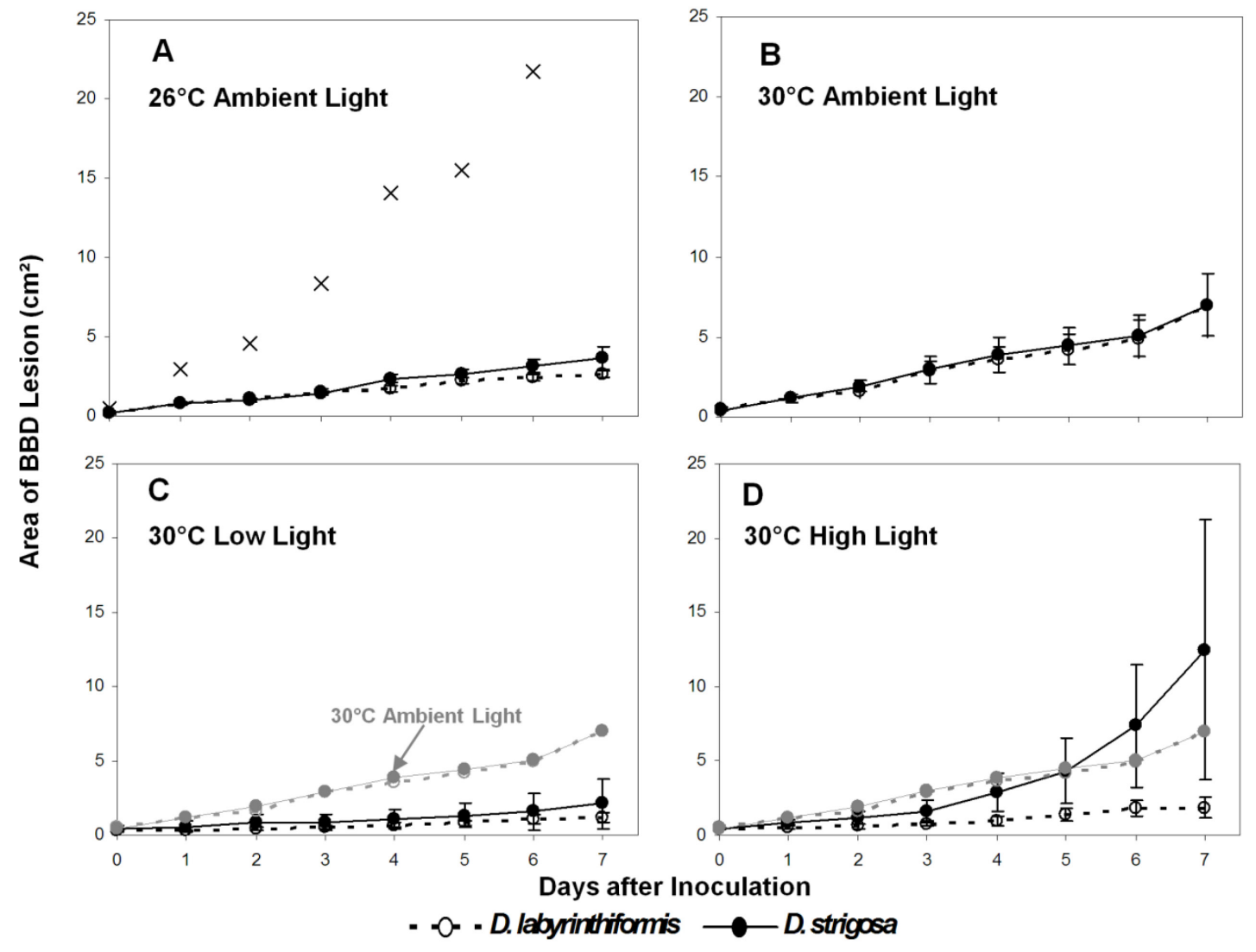

Figure 2 


\title{
CHAPTER III
}

\section{MICROBIAL COMMUNITIES ASSOCIATED WITH THE SURFACE MUCOPOLYSACCHARIDE LAYER OF HEALTHY AND BLACK BAND DISEASED COLONIES OF DIPLORIA IN BERMUDA}

\begin{abstract}
Black band disease (BBD) is a polymicrobial disease contributing to the global decline of coral reefs. On the reefs of Bermuda BBD-infected Diploria strigosa colonies are common whereas the coral species D. labyrinthiformis is rarely infected. Little is known regarding the ability of coral to resist disease but microbes present in the surface mucopolysaccharide layer (SML) may provide protection against invading pathogens. In this study the bacterial communities present in the SML of healthy corals and healthy areas of BBD-infected colonies of D. labyrinthiformis and D. strigosa were examined. Samples were collected from Hog Breaker Reef, an outer rim reef with minimal human impact, and Whalebone Bay, an inshore patch reef close to potential anthropogenic stressors. The BBD-infected $D$. strigosa colonies were found at both reef locations but BBD-infected D. labyrinthiformis was only present at the inshore location. The SML communities were characterized by amplicon length heterogeneity polymerase chain reaction (LH-PCR). LH-PCR profiles were compared between species and locations by one-way analysis of similarity (ANOSIM). While all SML samples collected from healthy corals on the same reef, regardless of coral species, were similar, the SML of colonies of D. labyrinthiformis and D. strigosa sampled at Hog Breaker Reef were
\end{abstract}


significantly different from the SML community patterns of the same host species sampled at Whalebone Bay. Profiles from the SML of healthy colonies of $D$. labyrinthiformis and D. strigosa were different than SML profiles from healthy areas of BBD-infected colonies. Nonmetric multidimensional scaling (NMDS) revealed that SML amplicons from healthy colonies at Whalebone Bay grouped with SML profiles of BBD-infected colonies. Our results suggest a shift in the microbial community either prior to the onset of disease or as a result of the infection.

\section{INTRODUCTION}

Disease of coral reef organisms is now recognized as a leading factor in the decline of reef ecosystems, particularly in the wider Caribbean [33]. Increases in coral disease incidence, geographic distribution and host species range have occurred within the last four decades $[28,32]$. At present there are 18 described diseases affecting one or more of 150 coral species worldwide [28]. Few attempts at identifying the causative agents of coral diseases have been successful $[1,15,20,17,27]$, and pathogen identification is complicated by an abundance of microbes in the water column and in association with the coral host [5, 22]. Recent efforts have focused on characterizing the bacterial communities associated with non-diseased corals in order to better understand the role of microbes in coral health and disease $[2,6,8,9,10,22,23,30]$.

Healthy corals are associated with diverse and abundant microbial communities [22, 23]. Comparisons between water column bacteria and coral associated bacteria have revealed little overlap suggesting that the microbes are harbored by the coral rather than passively associated $[5,6,22]$. Further, bacterial communities associated with 
corals have been shown, using culture dependent and independent techniques, to be distinct for different coral species [5, 18, 22, 23]. Ritchie and Smith demonstrated that microbes cultured from the surface mucopolysaccharide layer (SML) of different coral species have distinct carbon source utilization patterns [19].

Research has shown that the microbial communities associated with diseased and healthy corals are different $[4,14,18]$. Ritchie and Smith reported a decrease in the diversity of microbes associated with colonies of Acropora cervicornis showing signs of white band disease compared with healthy colonies of the same species [18]. Similarly, the bacterial community associated with colonies infected with black band disease (BBD) was less diverse than communities associated with healthy colonies [4]. In contrast, Pantos and colleagues reported an increase in microbial diversity in colonies of Montastraea annularis with tissue lesions consistent with white plague-like disease when compared to colonies lacking signs of disease [14]. These findings suggest that there may be a dynamic interaction between coral associated bacteria and disease.

Determining which bacteria may be involved in disease resistance is of particular interest. It has been proposed that corals may obtain a health benefit by associating with certain bacteria (the Coral Probiotic Hypothesis) [16]. Non-pathogenic microbes may provide protection against coral disease through interspecific competition and/or by secreting compounds that inhibit potential pathogens $[8,14]$. Ritchie detected antimicrobial activity in $20 \%$ of microbes isolated from the SML of A. palmata [21]. Castillo and colleagues similarly reported antibiotic capabilities in 30\% of coral associated bacteria [3]. 
Abiotic stressors, including degraded water quality, temperature extremes, and elevated irradiance, have been shown to alter the composition of microbes associated with corals $[6,9,10,30]$. Shifts in the microbial community composition may affect coral health and influence susceptibility to disease.

The aim of the present study was to analyze and compare the microbial communities associated with BBD-susceptible and BBD-resistant coral species. On the reefs of Bermuda, colonies of Diploria labyrinthiformis are rarely infected with BBD, a polymicrobial disease dominated by filamentous cyanobacteria, whereas BBD-infected colonies of D. strigosa are common [7,24]. The bacterial communities present in the SML of healthy colonies, and in the SML of healthy areas of BBD infected colonies of D. strigosa and D. labyrinthiformis were characterized by amplicon length heterogeneity polymerase chain reaction (LH-PCR). Length heterogeneity PCR is a molecular profiling technique that distinguishes bacteria by intrinsic variation in the sequence length of hypervariable domains of the 16S rRNA gene [29]. This technique was chosen as it has been shown to be a highly reproducible method for quantitatively examining differences between microbial communities [13, 25, 29, 31]. Length heterogeneity PCR has successfully been used to profile communities associated with BBD and SML $[25,31]$.

\section{METHODS}

\section{Sampling location and collection}

In July of 2007 SML samples from ten healthy colonies each of $D$. labyrinthiformis and D. strigosa, and from apparently healthy tissue of eight BBD- 
infected $D$. strigosa colonies, were collected at a depth of approximately seven meters from Hog Breaker reef $\left(32^{\circ} 27.55 \mathrm{~N}^{\prime}\right.$ and $\left.64^{\circ} 49.89^{\prime} \mathrm{W}\right)$, a northern rim reef of Bermuda

(Figure 1). In August of 2007 and 2008 SML samples were also collected from healthy colonies of $D$. labyrinthiformis $(\mathrm{N}=10), D$. strigosa $(\mathrm{N}=7)$, and from the apparently healthy region of BBD-infected colonies of D. labyrinthiformis $(\mathrm{N}=3)$ and D. strigosa $(\mathrm{N}=2)$ on the shallow $\left(<5 \mathrm{~m}\right.$ deep) patch reefs $100 \mathrm{~m}$ north of Whalebone Bay $\left(32^{\circ}\right.$ $21.58 \mathrm{~N}^{\prime}$ and $\left.64^{\circ} 42.53^{\prime} \mathrm{W}\right)$. Colonies were considered healthy if they lacked signs of disease and/or bleaching. The SML was sampled approximately $10 \mathrm{~cm}$ distant from the band on BBD-infected colonies.

The SML was aspirated into individual sterile, $10 \mathrm{ml}$ needless syringes by gently scouring the surface of the coral with the tip of the syringe. After collection, SML samples were floated in ambient temperature water under low light until return to the Bermuda Institute of Ocean Sciences (BIOS) field station (ca. 2 hours). At BIOS, the syringes were oriented vertically on ice to allow the SML to settle to the tip of the syringes (ca. $10 \mathrm{~min}$ ). SML was then carefully transferred into sterile $2 \mathrm{ml}$ cryovials for immediate DNA extraction.

DNA extraction

Whole community genomic DNA was extracted from the SML samples using the FastDNA SPIN kit for soil (Q-Biogene, Vista, CA) with a slight modification as previously described by Mills and colleagues [12]. Refer to Appendix A for protocol details. 
Amplicon-length heterogeneity (LH) PCR

The V1+V2 hypervariable domains of the bacterial 16S rRNA gene were amplified using the fluorescently labeled forward primer 27F-6-FAM (5'-6-FAM-AGA GTT TGA TCM TGG CTC AG-3') and the unlabelled reverse primer 355R (5'-GGT GCC TCC CGT AGG AGT-3') as previously described by Sekar et al. (2006) and Voss et al. (2007). The PCR products were processed at the International Forensic Research Institute's DNA Profiling Facility at Florida International University, Miami, FL. In depth protocol details can be found in Appendix A.

\section{Statistical analysis}

Primer v5 software (Primer-E, Plymouth, UK) was used for all statistical analyses. Prior to statistical analyses, the abundance data were square root transformed to minimize the effects of dominant amplicons, and Bray-Curtis similarity matrices were calculated. Analysis of similarity (ANOSIM) was used to test for variations among profiles from healthy and BBD-infected colonies of D. labyrinthiformis and D. strigosa and between colonies collected at Hog Breaker reef vs. colonies collected at Whalebone Bay. The contribution of each amplicon to the dissimilarity between groups was determined by similarity percentage (SIMPER) analyses. Differences between community assemblages were visualized using nonmetric multidimensional scaling (NMDS) with 20 random starting configurations.

\section{RESULTS}

Variability of LH-PCR profiles by host coral species and reeflocation 
Comparisons of the LH-PCR profiles produced from the SML of healthy colonies of D. strigosa $(\mathrm{N}=7$, Whalebone Bay; $\mathrm{N}=10$, Hog Breaker Reef $)$ and $D$. labyrinthiformis $(\mathrm{N}=10$ at both Whalebone Bay and Hog Breaker Reef) revealed that the SML microbial community composition of the two coral species at either Hog Breaker Reef (ANOSIM Global $R=0.047, \mathrm{p}=0.2$ ) or Whalebone Bay (ANOSIM Global $R=0.129, \mathrm{p}=0.07$ ) were not statistically discriminate and that the average similarity among and between groups was much the same.

Profiles for D. labyrinthiformis and D. strigosa at each location are shown in Figure 2. Nineteen amplicons ranging in length from 311-380 bp were present in the SML of healthy colonies of both species of Diploria from Hog Breaker Reef (Figure 2A). Fourteen and 13 amplicons were present in the SML of D. labyrinthiformis and $D$. strigosa, respectively. Three amplicons of lengths 314,342 and 349 bp dominated the community profiles of both D. strigosa and D. labyrinthiformis colonies at Hog Breaker Reef, with amplicon 342 the most abundant at nearly $60 \%$ (relative abundance). While the SML community profiles were similar between the host species, several amplicons were present that were unique to each species with six amplicons specific to $D$. labyrinthiformis and five to D. strigosa (Table 1).

The microbial communities in the SML of healthy colonies of $D$. labyrinthiformis and D. strigosa at Whalebone Bay were more diverse and evenly distributed in abundance than at Hog Breaker, with a total of 28 amplicons that also ranged from 311 and $380 \mathrm{bp}$ (Figure 2B). The community profiles of both species at Whalebone were dominated by amplicons of 314, 316, 342 and 346 bp in length. 
Several amplicons specific to this location were common to both $D$. strigosa and $D$. labyrinthiformis (Table 1). Seven out of 24 amplicons present in SML collected from $D$. labyrinthiformis colonies were unique (Table 1). The unique amplicon of length $327 \mathrm{bp}$ represented approximately $15 \%$ of the total amplicon abundance in the SML of $D$. labyrinthiformis, while two amplicons (342 and $346 \mathrm{bp}$ ) represented 13\% and 16\% of the total, respectively (Figure 2B). Twenty-one amplicons, four of which were unique, were associated with the SML of D. strigosa colonies (Table 1).

The 342 bp amplicon was the dominant amplicon (56\%) in the Hog Breaker profiles of both Diploria species; however there was an approximate 4-fold reduction in abundance of this amplicon in the SML of both D. labyrinthiformis (13\%) and $D$. strigosa $(15 \%)$ colonies collected at Whalebone Bay. Similarly, there was a reduction, in the SML of both species, in the abundance of amplicon 349 (from 12 to 2\%) between Hog Breaker and Whalebone Bay. Amplicon 346 increased in abundance in the SML of D. strigosa (4 to $17 \%$ ) and D. labyrinthiformis (2 to $16 \%$ ) sampled at Hog Breaker and Whalebone Bay, respectively.

While the community compositions of bacteria in the SML of colonies of $D$. labyrinthiformis and D. strigosa sampled at Hog Breaker Reef were similar when compared to each other, they varied greatly from the SML community patterns of the same host species sampled at Whalebone Bay (ANOSIM; D. labyrinthiformis: Global $R$ $=0.601, \mathrm{p}=0.001 ;$ D. strigosa: Global $R=0.626, \mathrm{p}=0.001)$. There were more amplicons that were specific to location, as compared to host species (Table 1). This pattern was true, for the most part, for both species. For example, at Whalebone bay 16 
amplicons were location-specific to D. strigosa whereas only four amplicons were species-specific. In one case (D. labyrinthiformis at Hog Breaker) there were only two location-specific amplicons. Table 2 presents the amplicons that contributed to the dissimilarity between species at both sampling locations.

Variability between bacterial communities in the SML of healthy areas of BBD diseased colonies and the SML of healthy corals

Figure 3 shows bacterial community profiles present in the SML of healthy areas of BBD diseased colonies, and SML of healthy corals, of both coral species at Whalebone Bay. The microbial community in the SML differed between healthy $(\mathrm{N}=$ 10) and BBD-infected $(\mathrm{N}=3)$ colonies of $D$. labyrinthiformis (ANOSIM Global $R=$ $0.572, \mathrm{p}<0.007)$. For this coral species the bacterial community profile associated with the SML of BBD-infected colonies was less diverse, with 10 amplicons as compared to 24 amplicons associated with the SML of healthy D. labyrinthiformis colonies (Figure 3A). Fifteen and two amplicons were specific to healthy and BBD-infected $D$. labyrinthiformis colonies, respectively (Table 3). The reduction in amplicon richness was accompanied by an increase in abundance of amplicon 342 bp from $13 \%$ in healthy colonies to $65 \%$ in BBD-infected colonies. Amplicons contributing to the dissimilarity in the microbial community composition in the SML between healthy and diseased colonies of D. labyrinthiformis are shown in Table 4.

For D. strigosa sampled at Whalebone Bay (Figure 3B) there were differences in the microbial community profiles of SML from healthy ( $\mathrm{N}=7$ colonies) and BBDinfected colonies $(\mathrm{N}=2)$; ANOSIM Global $R=0.049, \mathrm{p}=0.44)$. For this species there 
was, again, a reduction in amplicon richness in diseased colonies (Figure 3B). Twentyone amplicons were present in the SML of healthy colonies compared to seven amplicons present in BBD-infected colonies. At Whalebone Bay fifteen amplicons associated with the SML of healthy colonies were not found in the SML of BBDinfected colonies and one amplicon was specific to BBD-infected colonies (Table 3). Amplicon 342 bp again dominated the SML of BBD-infected D. strigosa colonies, as was the case for BBD-infected D. labyrinthiformis, but at a lower abundance (34\%).

Figure 4 shows the community profiles of the SML of healthy areas of BBDinfected colonies and the SML of healthy corals of D. strigosa at Hog Breaker Reef (there were no BBD-infected D. labyrinthiformis at this site). Significant variation in SML microbial community composition was documented between healthy $(\mathrm{N}=10)$ and BBD-infected ( $\mathrm{N}=8$ colonies) colonies (ANOSIM global $R=0.477, \mathrm{p}<0.005$; Table 5) at this site. In contrast to the large difference in SML amplicon diversity for BBD vs. healthy corals at Whalebone Bay (10 vs. 24 for D. labyrinthiformis and 7 vs. 21 for $D$. strigosa, respectively), there was a small increase in the number of amplicons present in the SML of BBD-infected D. strigosa at Hog Breaker Reef. For this species at this location there were 15 amplicons in the SML of BBD and 13 in the SML of healthy colonies. The SML of BBD-infected D. strigosa colonies had six amplicons that were absent in the SML of healthy colonies and four amplicons were specific to the SML of healthy colonies (Table 3). In contrast to Whalebone Bay, the abundance of the $342 \mathrm{bp}$ amplicon decreased from $57 \%$ in the SML of healthy colonies to $37 \%$ in the SML of healthy areas of BBD-infected colonies (Figure 4). 


\section{Overall comparisons of SML microbial communities}

Results of NMDS using amplicons from all healthy SML samples from both locations and comparing by coral host species showed substantial overlap (Figure 5A). In contrast, there was distinct clustering when amplicons of both species (combined) were compared by location (Figure 5B). Ordination of all SML profiles in the data set, i.e., from both healthy and BB-diseased colonies of both D. labyrinthiformis (Whalebone Bay) and D. strigosa (both locations) demonstrated a clustering of amplicons from the SML of BBD-infected colonies, regardless of species or location (Figure 5C). This analysis also revealed that SML amplicons from healthy colonies at Whalebone Bay were grouped closer to the BBD-infected profiles than were healthy SML amplicons from Hog Breaker Reef.

\section{DISCUSSION}

Variability of LH-PCR profiles by host coral species and reef location

Analysis of LH-PCR profiles from the SML of colonies collected at Hog Breaker Reef and at Whalebone Bay demonstrated that the bacterial communities in the SML of corals collected from the same reef, regardless of species, were similar while those between sites were significantly different. In other words, location rather than host species seems to be driving the microbial diversity in the SML. The bacterial profiles of both $D$. labyrinthiformis and $D$. strigosa were dominated by amplicons of the same lengths and relative abundances which suggests that the observed difference in BBD prevalence between these two species may be attributed to factors other than the microbial communities present within the SML. On the other hand, unique amplicons 
were associated with each species, and there may be specific bacteria in the SML that play a role in susceptibility to BBD.

Amplicons of different lengths can indicate phylogenetic differences, although it is also possible for multiple organisms to produce amplicons of the same length albeit with different sequences [29]. In the present study cloning and sequencing was not utilized in conjunction with LH-PCR to identify SML bacteria corresponding to the different amplicon lengths. Instead, phylogenetic affiliations were inferred from previous studies that analyzed samples from marine environments.

Suzuki and colleagues, for example, determined the phylogentic relationships between amplicon lengths and marine bacteria by in silico analysis of bacterial isolates and clones from the same seawater sample [29]. Similarly, Sekar and colleagues combined LH-PCR and sequence analysis of clones obtained from the SML of two colonies of the coral Siderastrea siderea [25]. These studies both found that amplicons of lengths 313-316 bp correspond to cyanobacteria and $\alpha$-proteobacteria $[25,29]$. Amplicons of lengths 342 and 346 bp were shown to correspond to $\gamma$-protebacteria, $\beta$ proteobacteria and Cytophaga-Flavobacter/Flexibacter-Bacteriodes (CFB) [25, 29]. Amplicon 349 corresponded to CFB, $\gamma$-proteobacteria, $\delta$-proteobacteria [29] and $\alpha$ proteobacteria [25].

The SIMPER analyses revealed that variation observed in the SML bacterial profiles between sampling locations was primarily due to differences in the abundances of amplicons 342, 346 and 349. Amplicons 342 and 349 were the dominant amplicons in the Hog Breaker profiles whereas amplicon 346 was more abundant at Whalebone 
Bay. Species-specific differences between locations were associated with amplicon 327 (unknown phylogenetic affiliation) which was only present in the SML of $D$. labyrinthiformis at Whalebone Bay. Amplicon 314 was more abundant in the SML of D. strigosa at Whalebone Bay and amplicon 316 was absent in the SML of this species at Hog Breaker.

Rohwer and colleagues similarly reported differences in the abundance of microbes associated with healthy colonies of D. strigosa at these same two Bermuda reef sites [23]. On the basis of clone libraries, they found an abundance of bacterial ribotypes isolated from colonies at Whalebone Bay as follows: 13\% $\gamma$-proteobacteria, 7\% $\alpha$-proteobacteria, 43\% CFB, 32\% Bacillus/Clostridium (BC) and 5\% other. Ribotypes isolated from colonies at Hog Breaker reef included $\gamma$-proteobacteria (15\%), $\alpha$-proteobacteria (11\%), CFB (28\%), BC (24\%), cyanobacteria (12\%) and other (10\%).

The differences in microbial community composition between the two Bermuda reef sites detected by Rohwer and colleagues [23] and within the present study may be influenced by proximity to potential anthropogenic stressors, as has been found in other studies [26]. Hog Breaker Reef is located approximately nine miles north of mainland Bermuda whereas the reefs sampled at Whalebone Bay fringe the shoreline. Guppy and Bythell reported similar results when comparing microbial communities associated with the coral Montastrea faveolata at five sites in Tobago that differed with respect to water quality and proximity to the mainland [6]. 
Variability between bacterial communities in the SML of healthy areas of BBD diseased colonies and the SML of healthy corals

The LH-PCR analysis revealed significant variation in bacterial communities in the SML of healthy corals and the healthy region of BBD-infected colonies of $D$. labyrinthiformis at Whalebone Bay and D. strigosa at Hog Breaker Reef. The SML communities from the two BB-diseased colonies of D. strigosa at Whalebone Bay were not significantly different from the communities of healthy SML, although some variation was observed. A significant relationship may have been detected with a larger sample size of BBD-infected colonies $(\mathrm{N}=3)$.

Ordination of SML profiles from both healthy and BBD infected colonies of $D$. labyrinthiformis and D. strigosa revealed that the bacterial community profiles from healthy colonies of both species sampled at Whalebone Bay, a site potentially impacted by anthropogenic influences, grouped with profiles of BBD-infected colonies (from both locations) rather than with SML profiles from Hog Breaker Reef, the offshore site. These results suggest that microbial communities present in the SML of corals located at a potentially impacted site are similar to microbial communities associated with diseased corals. Anthropogenic influences may reduce the ability of corals to resist $\mathrm{BBD}$ as $\mathrm{BBD}$-infected colonies of D. labyrinthiformis (BBD resistant species) were only located at Whalebone Bay. These results also support the hypothesis that anthropogenic sources can serve as reservoirs of potential coral pathogens which can colonize healthy corals. Such pathogens could then become opportunistic, or secondary, pathogens. 
The SIMPER analyses revealed that differences in the bacterial communities associated with healthy and BBD-infected colonies at both reef locations were a result of variation in amplicons 342 and 346. The SML profiles of BBD-infected colonies of D. strigosa and D. labyrinthiformis sampled at Whalebone Bay were dominated by amplicon 342 accompanied by a reduction in amplicon 346 when compared to healthy SML profiles. Conversely, the abundance of amplicon 342 decreased while amplicon 346 increased in the SML profiles of BBD-infected colonies of D. strigosa from Hog Breaker Reef. Amplicons 342 and 346 were previously shown to correspond to $\gamma$ proteobacteria, $\beta$-proteobacteria and CFB $[25,29]$. Frias-Lopez and colleagues found BBD-infected colonies of $D$. strigosa to be predominantly associated with $\gamma$ proteobacteria [5] and Sekar and colleagues similarly reported a dominance of $\gamma$ proteobacteria in the SML of BBD-infected colonies of S. siderea [25]. Members of the $\gamma$-proteobacteria include bacteria in the genus Vibrio, which are known marine pathogens [11].

The finding that bacterial communities in the SML of BBD-infected D. strigosa and D. labyrinthiformis at Whalebone Bay were much less diverse than those associated with healthy colonies is in agreement with previous studies that reported a reduction in microbial diversity in diseased corals $[4,18]$. However, this pattern was not observed in samples from Hog Breaker Reef, in which there was a slight increase in the number of different amplicons in the SML of BBD-infected D. strigosa. This second pattern has also been reported in a study that compared bacterial communities associated with healthy and diseased colonies of M. annularis [14]. 
At this point the results of this and other studies indicate that variation in bacterial communities associated with healthy and diseased coral colonies exists, suggesting that coral-associated microorganisms respond to changes in coral health. To determine the specific roles of SML-associated bacteria in coral disease and their response to environmental drivers will require studies that combine microbial community profiling with techniques that identify specific bacterial taxa. 


\section{ACKNOWLEDGMENTS}

I would like to thank R. Jones for providing prevalence data, and J. Evered, D. Gibbs and C. Sleeter for field assistance. This work was funded by an Environmental Protection Agency Greater Research Opportunity Graduate Fellowship (MA91697601). This chapter was submitted for publication to the journal Microbial Ecology as "Kristin A. Kuehl, DeEtta K. Mills and Laurie L. Richardson. Microbial Communities Associated with the Surface Mucopolysaccharide Layer of Healthy and Black Band Diseased Colonies of Diploria in Bermuda." 


\section{REFERENCES}

1. Ben-Haim, Y, Thompson, FL, Thompson, CC, Cnockaert, MC, Hoste B, Swings, J, Rosenberg, E (2003) Vibrio coralliilytic sp. nov., a temperature dependent pathogen of the coral Pocillopora damicornis. Int J Syst Evol Microbiol 53: 309315

2. Bourne, DG, Munn, CB (2005) Diversity of bacteria associated with the coral Pocillopora damicornis from the Great Barrier Reef. Environ Microbiol 7: 1162117

3. Castillo, I, Lodeiros, C, Nunez, M, Campos, I (2001) In vitro study of antibacterial substances produced by bacteria associated with various marine organisms. Rev Biol Trop 49: 1213-1222

4. Cooney, RP, Pantos, O, Le Tissier, MD, Barer, MR, O'Donnell, AG, Bythell, JC (2002) Characterization of the bacterial consortium associated with black band disease in coral using molecular microbiological techniques. Environ Microbiol 4: 401-413

5. Frias-Lopez, JJ, Zerkle, AL, Bonheyo, GT, Fouke, BW (2002) Partitioning of bacterial communities between seawater and healthy, black band diseased, and dead coral surfaces. Appl Environ Microbiol 68: 2214-2228

6. Guppy, R, Bythell, JC (2006) Environmental effects on bacterial diversity in the surface mucus layer of the reef coral Montastrea faveolata. Mar Ecol Prog Ser 328: $133-142$

7. Jones, RJ (2006) Bermuda Institute of Ocean Sciences (BIOS), Marine Environmental Program (MEP) Annual report (2005-2006), submitted to the Bermuda Government Department of Environmental Protection, Ministry of the Environment.

8. Klaus, JS, Frias-Lopez, J, Bonheyo, GT, Heikoop, JM, Fouke, BW (2005) Bacterial communities inhabiting the healthy tissues of two Caribbean reef corals: interspecific and spatial variation. Coral Reefs 24: 129-137

9. Klaus, JS, Janse, I, Heikoop, JM, Sanford, RA, Fouke, BW (2007) Coral microbial communities, zooxanthellae and mucus along gradients of seawater depth and coastal pollution. Environ Microbiol 9: 1291-305

10. Kooperman, N, Ben-Dov, E, Kramarsky-Winter, E, Barak, Z, Kushmaro, A (2007) Coral mucus-associated bacterial communities from natural and aquarium environments. FEMS Microbiol Lett 276: 106-113 
11. Kushmaro, A, Banin, E, Loya, Y, Stackebrandt, E, Rosenberg, E (2001) Vibrio shiloi sp. nov., the causative agent of bleaching of the coral Oculina patagonica. Int J Syst Evol Microbiol 51: 1383-1388

12. Mills, DK, Fitzgerald, K, Litchfield, CD, Gilleve, PM (2003) A comparison of DNA profiling techniques for monitoring nutrient impacts on microbial community composition during bioremediation of petroleum-contaminated soils. $\mathrm{J}$ Microbial Methods 54:57-74

13. Mills, DK, Entry, JA, Gillevet, PM, Mathee, K (2007) Assessing microbial community diversity using amplicon length heterogenity polymerase chain reaction. SSSAJ 71: 572-578

14. Pantos, O, Cooney, RP, Le Tissier, MD, Barer, MR, O'Donnell, AG, Bythell, JC (2003) The bacterial ecology of a plague-like disease affecting the Caribbean coral Montastrea annularis. Environ Microbiol 5: 370-82

15. Patterson, KL, Porter, JW, Ritchie, KB, Polson, SW, Mueller, E, Peters, EC, Santavy, DL, Smith, GW (2002) The etiology of white pox, a lethal disease of the Caribbean elkhorn coral, Acropora palmata. Proc Natl Acad Sci U S A 99: 872530

16. Reshef, L, Omry, K, Loya, Y, Zilber-Rosenberg, I, Rosenberg, E (2006) The coral probiotic hypothesis. Environ Microbiol 8: 2068-73

17. Richardson, LL, Goldberg, WM, Kuta, KG, Aronson, RB, Smith, GW, Ritchie, KB, Halas, JC, Feingold, JS, Miller, SM (1998) Florida's mystery coral-killer identified. Nature 392: 557-558

18. Ritchie, KB, Smith, G (1995) Preferential carbon utilization by surface bacterial communities from water mass and white-band diseased Acropora cervicornis. Mol Mar Biol Biotech 4: 345-352

19. Ritchie, KB, Smith, G (1997) Physiological comparison of bacterial communities from various species of scleractinian corals. Proc 8th Int Coral Reef Symp 1:521526

20. Ritchie, KB, Smith, G (1998) Type II white-band disease. Rev Biol Trop 46: 199203

21. Ritchie, KB (2006) Regulation of microbial populations by coral surface mucus and mucus-associated bacteria. Mar Ecol Prog Ser 322: 1-14

22. Rohwer, F, Breitbart M, Jara J, Azam F, Knowlton, N (2001) Diversity of bacteria associated with the Caribbean coral Montastrea franksi. Coral Reefs 20: 85-95 
23. Rohwer, F, Seguritan, V, Azam, F, Knowlton, N (2002) Diversity and distribution of coral-associated bacteria. Mar Ecol Prog Ser 243: 1-10

24. Rützler K, Santavy, DL, Antonius, A (1983) The black band disease of Atlantic reef corals. III. Distribution, Ecology and Development. PSZN I: Mar Ecol 4: 329358

25. Sekar, R, Mills, DK, Remily, ER, Voss, JD, Richardson, LL (2006) Microbial communities in the surface mucopolysaccharide layer and the black band microbial mat of black band-diseased Siderastrea siderea. Appl Environ Microbiol 72: 5963-73

26. Sekar, R, Kaczmarsky, L, Richardson, LL (2008) Microbial community composition of black band disease on the coral host Siderastrea siderea from three regions of the wider Caribbean. Mar Ecol Prog Ser 362:38-98

27. Smith, GW, Harvell, CD, Kim, K (1998) Response of sea fans to infection with Aspergillus sp. (Fungi). Rev Biol Trop 46: 205-208

28. Sutherland, KP, Porter, JW, Torres, C (2004) Disease and immunity in Caribbean and Indo-Pacific zooxanthellate corals. Mar Ecol Prog Ser 266: 273-302

29. Suzuki, M, Rappe, MS, Giovannoni, SJ (1998) Kinetic bias in estimates of coastal picoplankton community structure obtained by measurements of small-subunit rRNA gene PCR amplicon length heterogeneity. Appl Environ Microbiol 64: $4522-4529$

30. Vega Thurber, R, Willner-Hall, D, Rodriguez-Mueller, B, Desnues, C, Edwards, RA, Angly, F, Dinsdale, E, Kelly, L, Rohwer, F (2009) Metagenomic analysis of stressed coral holobionts. Environ Microbiol 11: 2148-2163

31. Voss, JD, Mills, DK, Myers, JL, Remily, ER, Richardson, LL (2007). Black band disease microbial community variation on corals in three regions of the wider Caribbean. Microb Ecol 54: 730-739

32. Ward, JR, Lafferty, KD (2004) The elusive baseline of marine disease: are diseases in ocean ecosystems increasing? PLoS Biol 2: E120

33. Weil, E, Smith, G, Gil-Agudelo, DL (2006) Status and progress in coral reef disease research. Dis Aquat Organ 69: 1-7 
Table 1. Amplicons specific to the SML of healthy corals of each species and specific to sampling location.

\begin{tabular}{|c|c|c|c|c|}
\hline & \multicolumn{2}{|c|}{ D. labyrinthiformis } & \multicolumn{2}{|c|}{ D. strigosa } \\
\hline & Hog Breaker & Whalebone & Hog Breaker & Whalebone \\
\hline $\begin{array}{l}\text { Species specific } \\
\text { amplicons }\end{array}$ & $\begin{array}{c}316,320 \\
328,354,361 \\
380\end{array}$ & $\begin{array}{c}311,327 \\
352,355, \\
360,362 \\
380\end{array}$ & $\begin{array}{c}311,317,329 \\
353,362\end{array}$ & $\begin{array}{l}319,350 \\
359,371\end{array}$ \\
\hline $\begin{array}{l}\text { Location specific } \\
\text { amplicons }\end{array}$ & 320,326 & $\begin{array}{c}311,313, \\
315,327,330, \\
334,345,348, \\
352,357,362, \\
379\end{array}$ & $\begin{array}{c}311 \\
317,326,329 \\
353,355,360 \\
362\end{array}$ & $\begin{array}{c}313,315, \\
316,319,328, \\
330,334,345, \\
348,350,354, \\
357,359,361, \\
371,379\end{array}$ \\
\hline
\end{tabular}


Table 2. SIMPER analysis of variation between SML community profiles of healthy corals between locations.

\begin{tabular}{|c|c|c|c|c|}
\hline Amplicon (bp) & \multicolumn{2}{|c|}{ Mean abundance (\%) } & Dissimilarity (\%) & Cumulative (\%) \\
\hline D. strigosa & Hog Breaker & Whalebone Bay & & \\
\hline 342 & 57 & 16 & 35.4 & 35.4 \\
\hline 346 & 4 & 17 & 13.2 & 48.6 \\
\hline 314 & 11 & 14 & 9.1 & 57.7 \\
\hline 349 & 12 & 2 & 8.6 & 66.3 \\
\hline 316 & 0 & 10 & 7.8 & 74.1 \\
\hline D. labyrinthiformis & Hog Breaker & Whalebone Bay & & \\
\hline 342 & 56 & 17 & 34.1 & 34.1 \\
\hline 327 & 0 & 14 & 11.9 & 46 \\
\hline 346 & 2 & 15 & 11.7 & 57.7 \\
\hline 349 & 12 & 2 & 8.5 & 66.2 \\
\hline 316 & 0.5 & 8 & 6.9 & 73.1 \\
\hline
\end{tabular}

Amplicons contributing to greater than $5 \%$ of the dissimilarity between the locations are listed. The cumulative $\%$ refers to the cumulative contribution of amplicons to the dissimilarity between groups. 
Table 3. Amplicons specific to the SML of healthy colonies and the SML of BBDinfected colonies.

\begin{tabular}{ccccc}
\hline & \multicolumn{2}{c}{$D$. labyrinthiformis } & \multicolumn{2}{c}{ D. strigosa } \\
\hline & Healthy & Diseased & Healthy & Diseased \\
& $311,327,328$, & 317,329 & $313,315,316$, & 317 \\
Whalebone & $330,334,339$, & & $319,328,330$, & \\
Bay & $346,348,352$, & & $334,339,345$, & \\
& $354,357,360$, & & $348,350,354$, & \\
& $362,379,380$ & & $357,359,371$ & \\
Hog Breaker & - & & $311,329,353$, & $315,316,340$, \\
\end{tabular}


Table 4. SIMPER analysis of variation between the SML of healthy and BBD-infected colonies.

\begin{tabular}{|c|c|c|c|c|}
\hline Amplicon (bp) & \multicolumn{2}{|c|}{ Mean abundance (\%) } & Dissimilarity (\%) & Cumulative (\%) \\
\hline \multicolumn{5}{|c|}{ Whalebone Bay } \\
\hline D. labyrinthiformis & Healthy & BBD-infe & & \\
\hline 342 & 17 & 65 & 37.6 & 37.6 \\
\hline 346 & 15 & 0 & 11.2 & 48.8 \\
\hline 327 & 14 & 0 & 10.8 & 59.6 \\
\hline 349 & 2 & 14 & 9.5 & 69.1 \\
\hline 316 & 8 & 3 & 6.1 & 75.2 \\
\hline 314 & 11 & 4 & 5.1 & 80.3 \\
\hline \multicolumn{5}{|c|}{ Whalebone Bay } \\
\hline D. strigosa & Healthy & BBD-infe & & \\
\hline 342 & 16 & 34 & 26.1 & 26.1 \\
\hline 346 & 17 & 2 & 15.8 & 41.9 \\
\hline 314 & 14 & 3 & 11.8 & 53.7 \\
\hline 316 & 10 & 0 & 9 & 62.7 \\
\hline 349 & 2 & 7 & 6.4 & 69.1 \\
\hline 313 & 6 & 0 & 5.8 & 74.9 \\
\hline 379 & 5 & 3 & 5.1 & 80 \\
\hline \multicolumn{5}{|c|}{ Hog Breaker } \\
\hline D. strigosa & Healthy & BBD-infe & & \\
\hline 342 & 57 & 37 & 33 & 33 \\
\hline 346 & 4 & 14 & 16.9 & 49.9 \\
\hline 314 & 11 & 2 & 14 & 63.9 \\
\hline 349 & 12 & 6 & 10.4 & 74.3 \\
\hline 340 & 0 & 5 & 6.8 & 81.1 \\
\hline
\end{tabular}

Amplicons contributing greater than 5\% of the dissimilarity between the locations are listed. The cumulative \% refers to the cumulative contribution of amplicons to the dissimilarity between groups. There were no BBD infected colonies of $D$. labyrinthiformis at Hog Breaker. 
Table 5. Summary of ANOSIM analysis of LH-PCR profiles compared by coral species, sampling location and coral health status. Comparisons by species are represented by DST:DL (D. strigosa: D. labyrinthiformis). Analysis between locations and health status are denoted by HB:WB (Hog Breaker: Whalebone Bay) and H:D (healthy: diseased) respectively. Significant differences are denoted by asterisks.

\begin{tabular}{ccccc}
\hline Sample & Location & Health Status & Global $\boldsymbol{R}$ & p-value \\
\hline DST:DL & HB & H & 0.047 & 0.2 \\
DST:DL & WB & $H$ & 0.129 & 0.07 \\
DST & HB:WB & H & 0.626 & $0.001^{*}$ \\
DL & HB:WB & H & 0.601 & $0.001^{*}$ \\
DL & WB & H:D & 0.572 & $0.007^{*}$ \\
DST & WB & H:D & 0.049 & 0.44 \\
DST & HB & H:D & 0.477 & $0.001^{*}$ \\
\hline
\end{tabular}




\section{FIGURE LEGENDS}

Figure 1. Bermuda sampling locations. Map provided by R. Jones.

Figure 2. LH-PCR profiles of microbial communities associated with the SML of healthy colonies of Diploria labyrinthiformis and Diploria strigosa at (A) Hog Breaker Reef and (B) Whalebone Bay. Means ( $+\mathrm{SE}$ ) were calculated from $\mathrm{N}=10$ colonies of each species at Hog Breaker Reef and $\mathrm{N}=10$ colonies of $D$. labyrinthiformis and $\mathrm{N}=7$ colonies of D. strigosa at Whalebone Bay. Note different scales on Y-axes.

Figure 3. LH-PCR profiles of the SML of healthy colonies and the SML of healthy areas of black band diseased colonies of Diploria labyrinthiformis (A) and Diploria strigosa (B) at Whalebone Bay. Means $(+\mathrm{SE})$ were calculated from healthy $(\mathrm{N}=10)$ and BBD-infected $(\mathrm{n}=3)$ colonies of D. labyrinthiformis and healthy $(\mathrm{N}=7)$ and BBDinfected colonies $(\mathrm{N}=2)$ of D. strigosa.

Figure 4. LH-PCR profiles of the SML of healthy colonies and the SML of healthy areas of black band diseased colonies of Diploria strigosa at Hog Breaker Reef. Means ( $\pm \mathrm{SE})$ were calculated from healthy $(\mathrm{N}=10)$ and BBD-infected $(\mathrm{N}=8)$ colonies. 
Figure 5. Non-metric multidimensional scaling (NMDS) of (A) amplicons obtained from the SML of healthy colonies of Diploria labyrinthiformis and Diploria strigosa (samples of individual species from both locations combined); (B) amplicons obtained from the SML of both species of healthy corals compared by location; and (C) amplicons obtained from healthy and BBD-infected colonies of D. labyrinthiformis (Whalebone Bay only) and D. strigosa (both locations). Each point represents an individual sample with similar samples in close proximity to each other. 




Figure 1 


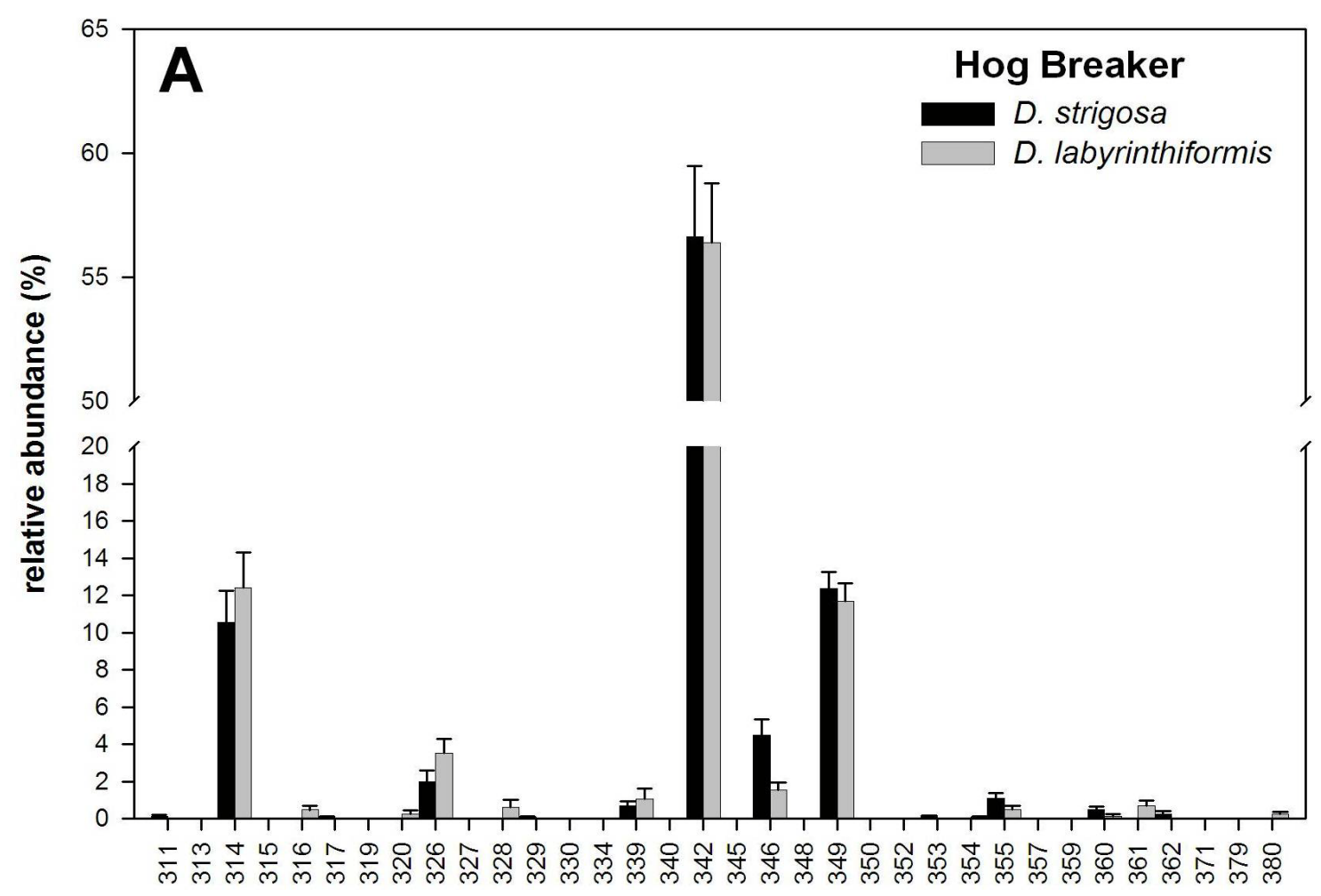

amplicon length (bp)

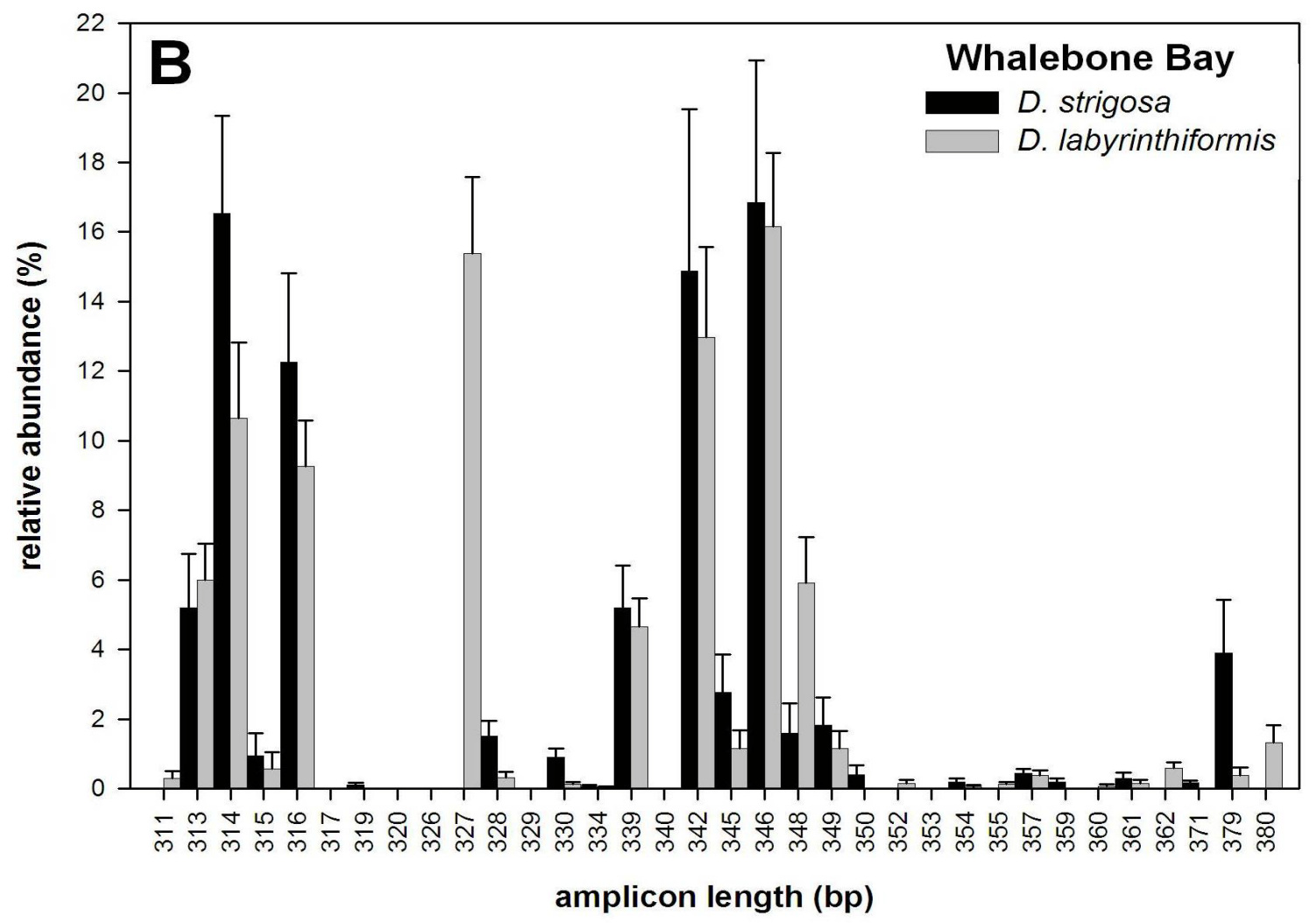

Figure 2 

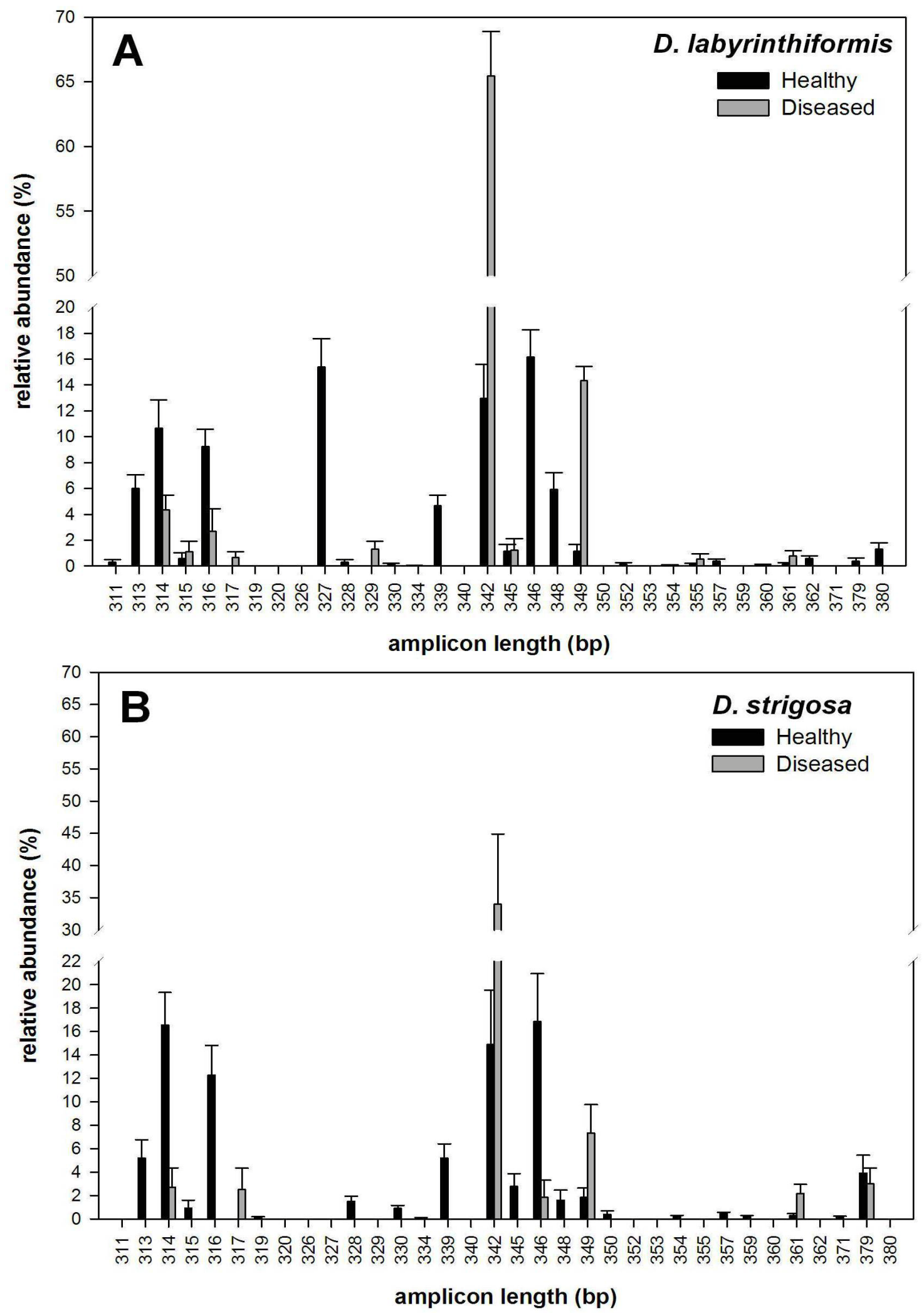

Figure 3 


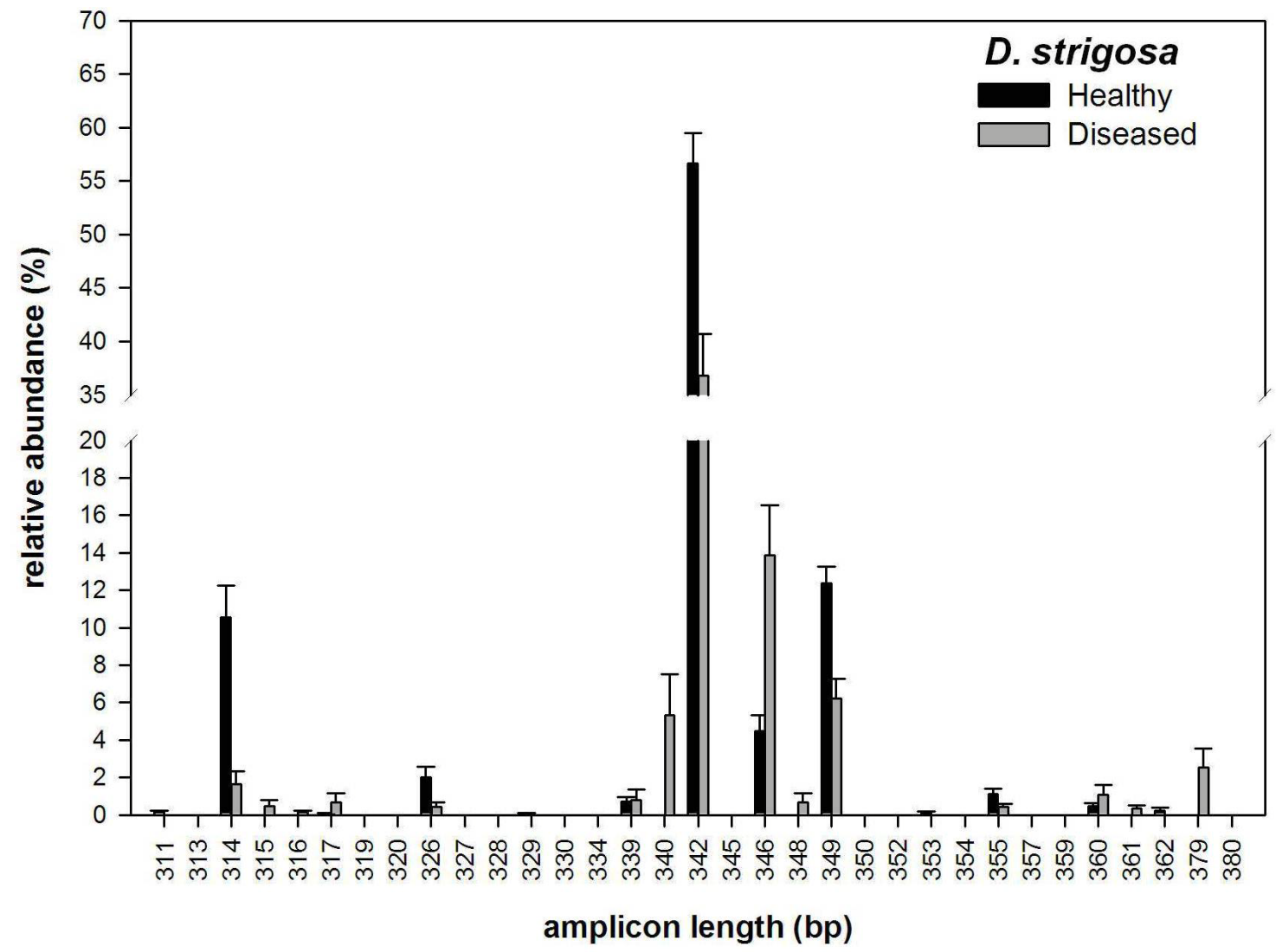

Figure 4 


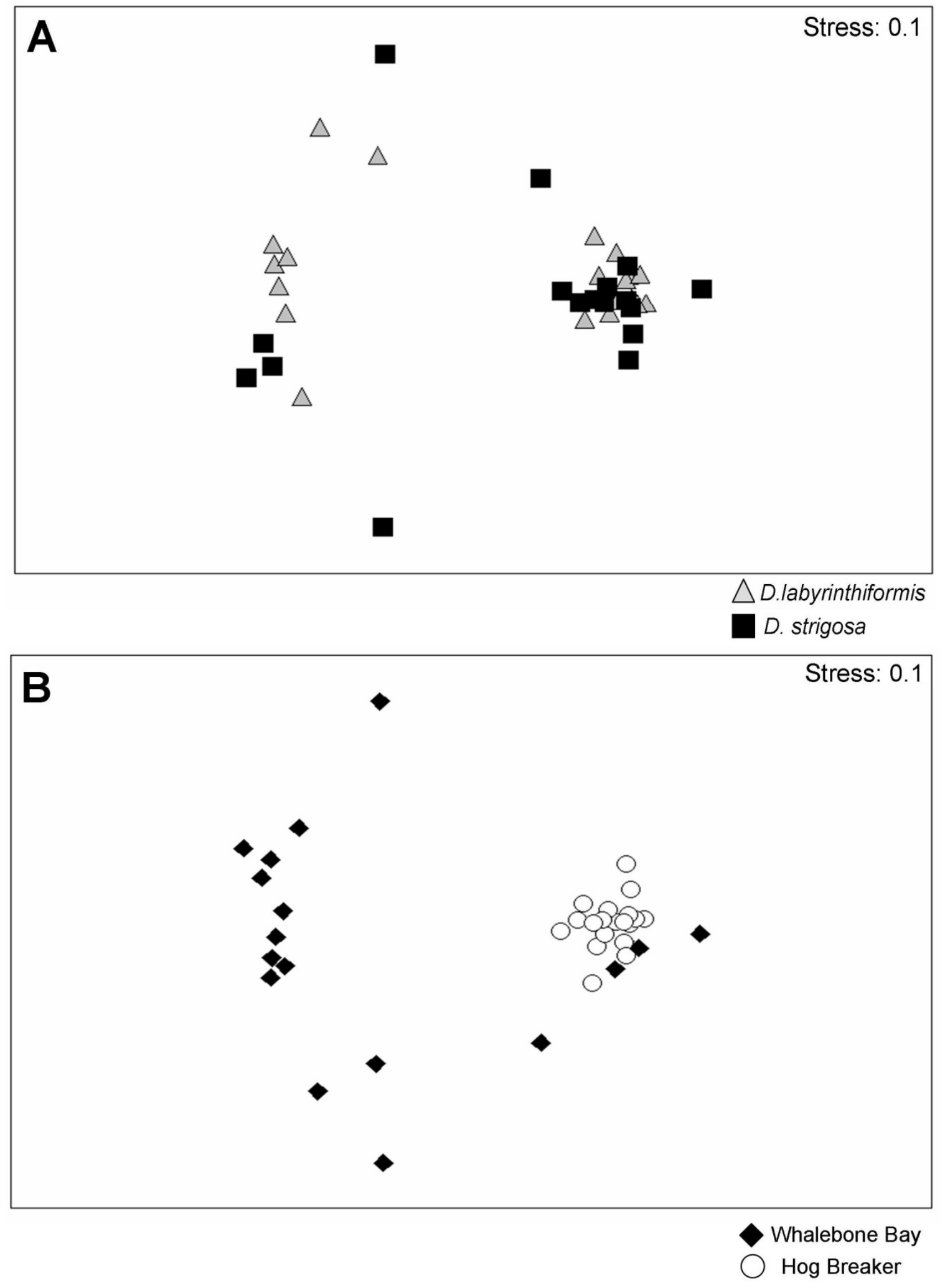




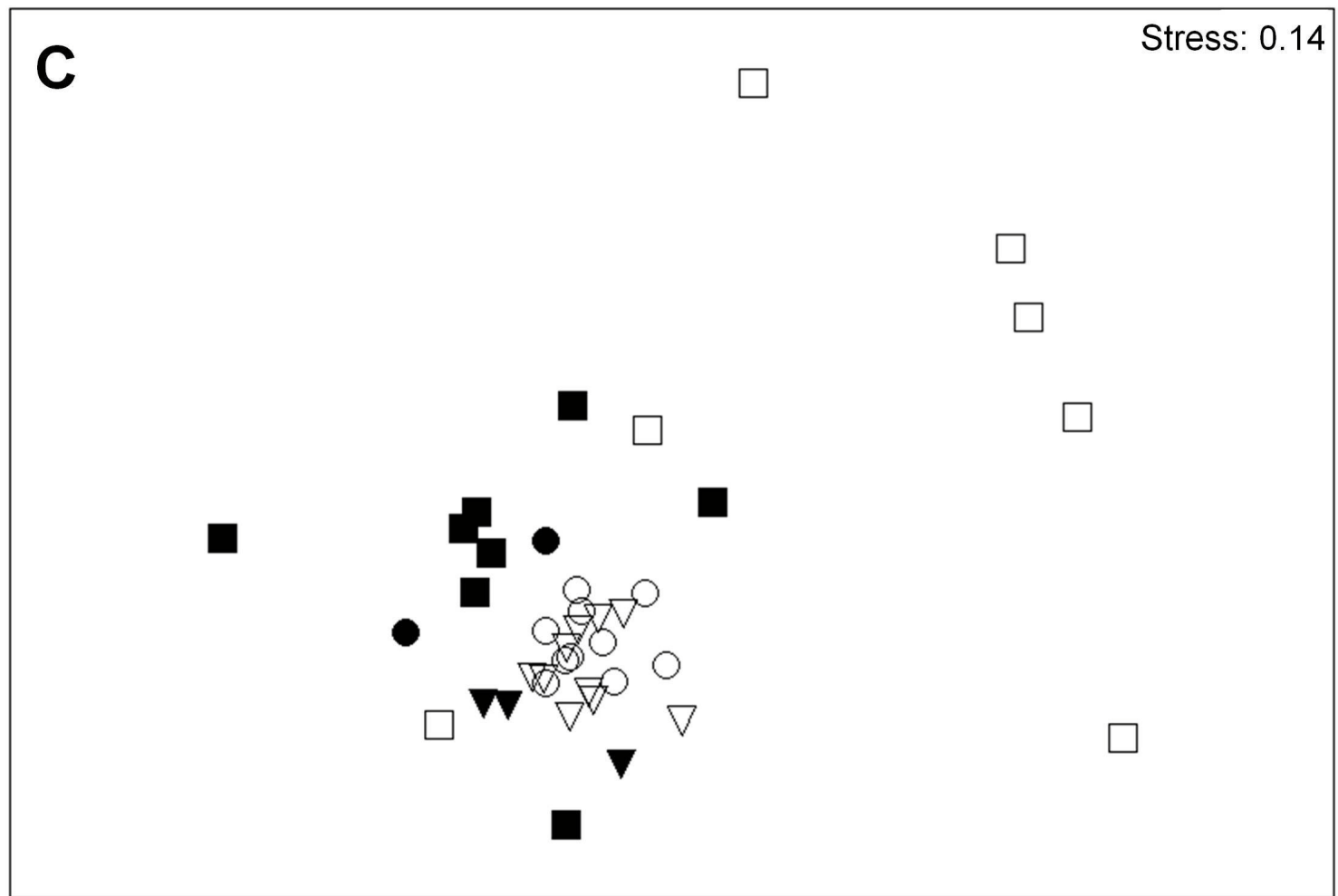

Hog Breaker

$\square$ Healthy $D$. strigosa

Diseased $D$. strigosa
Whalebone Bay

Healthy $D$. strigosa $\nabla$ Healthy $D$. labyrinthiformis

Diseased $D$. strigosa $\nabla$ Diseased $D$. labyrinthiformis

Figure 5 


\title{
CHAPTER IV
}

\section{A COMPARISON OF THE BACTERIAL COMPOSITION OF BLACK BAND DISEASE IN BERMUDA WITH THREE REGIONS IN THE CARIBBEAN}

\begin{abstract}
Black band disease (BBD) is one of the most ecologically important of the coral diseases because it targets large reef framework species. The band is formed by a diverse group of microorganisms that are dominated by filamentous cyanobacteria. Molecular analyses have revealed that the composition of microbes within the band is complex and variable by geographic region. Variation in the BBD microbial composition by location may contribute to regional differences in coral host susceptibility to BBD. The coral species Diploria strigosa and D. labyrinthiformis have been documented to be infected with $\mathrm{BBD}$ on reefs throughout the Caribbean. On the reefs of Bermuda, however, D. labyrinthiformis is rarely infected with BBD, while BBD-infected colonies of D. strigosa are common. The community composition of bacteria present in Bermuda BBD was characterized by amplicon length heterogeneity polymerase chain reaction (LH-PCR). Length heterogeneity PCR is a molecular profiling technique that distinguishes organisms based on variation in the sequence length of hypervariable domains within the 16S rRNA gene. The LH-PCR profiles of BBD in Bermuda were compared to published LH-PCR profiles of BBD collected from three other regions of the wider Caribbean: the Bahamas, U.S. Virgin Islands, and the Florida Keys. Analysis of the community profiles revealed that the bacterial community composition of BBD in Bermuda is distinct from the other regions sampled.
\end{abstract}


Multiple amplicons present in the Caribbean BBD samples were absent in Bermuda BBD samples, several amplicons were unique to BBD in Bermuda, and amplicons that were shared between regions were present in different abundances. This study represents the first molecular characterization of BBD from reefs of Bermuda.

\section{INTRODUCTION}

Coral reef ecosystems, particularly within the wider Caribbean, have experienced drastic reductions in both coral cover and species diversity since the 1970s (Sutherland et al., 2004). Emerging infectious diseases are one of the leading factors in the continued decline of coral reefs (Richardson, 1998; Weil et al., 2006). Black band disease (BBD) is among the most ecologically important of the known coral diseases as it preferentially targets large, reef building species (Rützler et al., 1983; Edmunds, 1991; Kuta and Richardson, 1996).

Black band disease appears as a dark migrating band that lyses coral tissue, leaving behind bare skeleton as it moves across the colony (Antonius, 1976).

Progression of the band varies between $3 \mathrm{~mm}$ to $>2 \mathrm{~cm}_{\text {day }}{ }^{-1}$ and is influenced by several environmental variables that include temperature, irradiance, and nutrient concentration (Kuta and Richardson, 2002; Kaczmarsky et al., 2005; Voss and Richardson, 2006; Boyett et al., 2007; Rodriguez and Croquer, 2008). The band is formed by a pathogenic microbial consortium that includes gliding filamentous cyanobacteria (Rützler and Santavy, 1983; Richardson and Kuta, 2003), sulfideoxidizing bacteria (Garrett and Ducklow, 1975; Richardson, 1996), sulfate-reducing bacteria (Viehman et al., 2006), numerous species of heterotrophic bacteria (Cooney et 
al., 2002; Frias-Lopez, 2002; Frias-Lopez et al., 2004; Sekar et al., 2006) and fungi (Ramos-Flores, 1983). Molecular analyses have revealed that the composition of microbes within the band is highly diverse and variable (Cooney et al., 2002; FriasLopez, 2002; Frias-Lopez et al., 2004; Sekar et al., 2006; Voss et al., 2007).

Voss et al. (2007) documented regionally distinct BBD microbial communities by use of amplicon length heterogeneity PCR (LH-PCR). Length heterogeneity PCR is a molecular profiling technique that distinguishes organisms based on natural variation in the sequence lengths of hypervariable regions within the 16S rRNA gene (Suzuki et al., 1998). Amplicons of different lengths generally indicate phylogenetic differences although it is possible for multiple organisms to produce amplicons of the same length albeit with different sequences (Suzuki et al., 1998). The use of LH-PCR is highly reproducible and time effective method for quantitatively examining differences in bacterial communities (Suzuki et al., 1998). Voss et al. (2007) examined 97 BBD samples collected from nine coral species in three regions of the Caribbean (Northern Florida Keys, Lee Stocking Island, Bahamas and St. John in the US Virgin Islands). Results of their analysis revealed that geographic location appeared to be more important than host species in determining the BBD microbial community assemblage (Voss et al., 2007).

Geographically distinct BBD microbial communities may contribute to regional differences in host susceptibility to BBD. The coral species Diploria strigosa and $D$. labyrinthiformis have been documented to be infected with BBD on reefs throughout the Caribbean (Edmunds, 1991; Green and Bruckner, 2000; Ward et al., 2006; Voss et 
al., 2007). On the high latitude reefs of Bermuda, however, D. labyrinthiformis is rarely observed to be infected with BBD while BBD-infected colonies of $D$. strigos $a$ are common (Jones, 2006). The aim of the present study was to use LH-PCR molecular profiling to characterize the bacterial communities of BBD in Bermuda and to compare these profiles to those published by Voss et al. (2007). This is the first molecular characterization of BBD on reefs of Bermuda.

\section{METHODS}

Sampling location and collection

The BBD samples were collected on August 15 and 19, 2008 from nine infected colonies of $D$. strigosa on the shallow $(<5 \mathrm{~m})$ patch reefs $100 \mathrm{~m}$ north of Whalebone Bay $\left(32^{\circ} 21.58 \mathrm{~N}^{\prime}\right.$ and $\left.64^{\circ} 42.53^{\prime} \mathrm{W}\right)$. During this sampling period there were no BBD infected colonies of D. labyrinthiformis present at this site. The BBD samples were collected and processed according toVoss et al. (2007), with samples individually drawn into sterile $10 \mathrm{ml}$, needleless syringes. Upon surfacing, excess seawater (ca. $8 \mathrm{ml}$ ) was decanted from syringes and BBD samples (in the syringes) were stored on ice in a cooler until return to the Bermuda Institute of Ocean Sciences (BIOS) field station (generally no longer than two hours). At BIOS, the BBD samples were aseptically transferred into sterile two $\mathrm{ml}$ cryovials and frozen at $-20{ }^{\circ} \mathrm{C}$ until further processing at Florida International University (FIU). The present study utilized the same methods for DNA extraction, DNA quantification and LH-PCR processing as described in Voss et al. (2007). 


\section{DNA extraction}

Genomic DNA was extracted from BBD samples on August 29, 2008 by use of the FastDNA SPIN kit for soil (Q-Biogene, Vista, CA), with a slight modification as previously described by Mills et al. (2003). The entire BBD sample (ca. $500 \mu 1$ ) was placed directly into Multimix lysing matrix tubes (BIO 101 Systems, Q-Biogene, California) and bead beaten in a FastPrep ${ }^{\circledR}$ instrument (Krackeler Scientific Inc., Albany, NY) for 20 seconds on speed setting 5.5. After a single elution in $50 \mu 1$ of sterile nuclease free-water (heated to $65^{\circ} \mathrm{C}$ ), the DNA extractions were verified using Tris-borate-EDTA (TBE) agarose gels $(1 \% \mathrm{wt} / \mathrm{vol})$ followed by staining with ethidium bromide. A Bio-Rad VersaFlour ${ }^{\mathrm{TM}}$ fluorometer (Richmond, CA, USA) was used to quantify DNA. To ensure the DNA extraction method resulted in reproducible LH-PCR profiles, sub-samples $(\mathrm{N}=2)$ of the BBD samples were extracted in duplicate.

Amplicon-length heterogeneity PCR

The V1+V2 regions of the hypervariable domain of the bacterial 16S rRNA gene were amplified using the fluorescently labeled forward primer 27F-6-FAM (5'-6FAM-AGA GTT TGA TCM TGG CTC AG-3') and the unlabelled reverse primer 355R (5'-GGT GCC TCC CGT AGG AGT-3'). Each reaction mixture contained 1x PCR buffer, $2.5 \mathrm{mM} \mathrm{MgCl}_{2}, 0.25 \mathrm{mM}$ of each deoxynucleoside triphosphate (Promega, Madison, WI), $0.5 \mu \mathrm{M}$ forward and reverse primer, 0.5 U AmpliTaq Gold DNA polymerase (Applied Biosystems, Foster City, CA), 0.1\% (wt/vol) bovine serum albumin (fraction V; Fisher, Suwannee, GA), $10 \mathrm{ng}$ of genomic DNA and nuclease-free water, for a final volume of $20 \mu \mathrm{l}$ (Voss et al., 2007; Sekar et al., 2006). Escherichia coli DNA was amplified for a positive control and nuclease-free water was used as a 
negative control. Amplifications were conducted in triplicate within a Peltier Thermal Cycler (PTC-200, MJ Research, Waltham, MA) with an initial denaturing step at $94{ }^{\circ} \mathrm{C}$ for $11 \mathrm{~min}$, followed by 25 cycles of $94{ }^{\circ} \mathrm{C}$ for $1 \mathrm{~min}, 55^{\circ} \mathrm{C}$ for $1 \mathrm{~min}, 72^{\circ} \mathrm{C}$ for $1 \mathrm{~min}$, with a final extension step at $72{ }^{\circ} \mathrm{C}$ for $10 \mathrm{~min}$ (Voss et al., 2007). The PCR products were verified using 1\% TBE agarose along with a 100 bp DNA ladder (Promega, Madison, WI) and 5x loading dye (Qiagen, Valencia, CA).

Samples were submitted to FIU's International Forensic Research Institute (IFRI) DNA Profiling Facility for LH-PCR processing. The PCR products $(0.5 \mu 1)$ were denatured with $9.5 \mu$ of 96:1 Hi-Dye ${ }^{\mathrm{TM}}$ deionized formamide to GeneScan ${ }^{\circledR}$ ROX 500 internal standard solution (Applied Biosystems (ABI), Foster City, CA, USA) and separated by size on a capillary electrophoresis ABI 310 DNA genetic analyzer. Samples were run using polymer POP-4, matrix DS-30_6FAM_HEX_NED_ROX and filter D. The resulting electropherograms (profiles) were analyzed using ABI's Prism GeneMapper ${ }^{\circledR}$ version 4.0 software. Analysis was limited to amplicons between 300 and 400 base pair (bp) in length. Size (bp) and relative abundance (fluorescence) of each amplicon were measured using the Local Southern (Size Calling) Method with no peak correction or smoothing. An amplicon was eliminated from analysis if it did not occur in at least two of the three replicate PCR reactions and abundance data were averaged among replicates. Amplicons were subsequently removed from analysis if they comprised less than $1.0 \%$ of the total relative abundance.

For LH-PCR profiling of BBD cyanobacterial isolates each laboratory culture was grown in a $250 \mathrm{ml}$ flask in ASNIII medium at $27^{\circ} \mathrm{C}$ and $30 \mu \mathrm{E} \mathrm{m} \mathrm{m}^{-2} \mathrm{~s}^{-1}$ under $24 \mathrm{~h}$ of 
constant cool-white light regime (Philips, F34T12/CW/RS/EW). After three weeks a small clump of biomass was transferred with sterile forceps from the flask into a $1.5 \mathrm{ml}$ eppendorf tube and submitted to IFRI's DNA profiling facility as above.

\section{RESULTS}

\section{LH-PCR bacterial profiles of BBD in Bermuda}

Nineteen amplicons ranging in length from 302 to 360 base pairs (bp) were detected in the BBD mat of nine infected colonies of D. strigosa in Bermuda. Amplicons of lengths 314,315 and 360 bp dominated the BBD community profile with approximate relative abundances of 17, 19 and 15\%, respectively (Figure 1). Three amplicons, 346, 350 and $352 \mathrm{bp}$, contributed 6-10\% of the relative abundance, and 2$5 \%$ of the amplicon abundance was attributed to amplicons 344, 347 and 357.

Two of the 19 amplicons were found in the BBD mat of all nine colonies sampled, several amplicons were associated with multiple BBD samples and two amplicons were only detected in one sample (Table 1).

A comparison of BBD profiles from Bermuda, the Northern Florida Keys, Bahamas and the US Virgin Islands

Bacterial community profiles from BBD mats collected in Bermuda were compared to representative BBD community profiles published by Voss et al. (2007) from the Northern Florida Keys, Lee Stocking Island, Bahamas and St. John in the US Virgin Islands. Fourteen amplicons reported by Voss et al. (2007) were not found in the Bermuda BBD profiles and seven amplicons were unique to Bermuda (Table 2). Seven amplicons were common between the Bermuda and Northern Florida Keys BBD 
community profiles. Six amplicons were shared between the Bermuda and Lee Stocking Island BBD profiles and the Bermuda and US Virgin Island profiles (Table 2). Amplicon lengths of cultures BBD cyanobacteria

Cyanobacteria, cultured from BBD sampled throughout the wider Caribbean, of the genera Geitlerinema, Leptolyngbya, and Oscillatoria had amplicon lengths of 313/315 bp, 314 bp, and 315 bp respectively (Table 3).

\section{DISCUSSION}

The LH-PCR analysis revealed that the bacterial community composition of BBD in Bermuda is distinct from the BBD composition reported in the Northern Florida Keys, Bahamas, and the US Virgin Islands. Multiple amplicons reported in BBD sampled from the three Caribbean regions were absent in Bermuda BBD samples and several amplicons were unique to BBD in Bermuda (Table 2). Further, several of the dominant amplicons (313-316 bp) common between regions were present at different abundances. Voss et al. (2007) reported that regional variation in BBD samples was largely the result of differences in the abundance of amplicons ranging from 313-316 bp in length. Amplicon 313 was absent in Bermuda BBD samples. An amplicon (314 bp) was present in Bermuda and US Virgin Island BBD profiles at abundances of 17 and $2 \%$, respectively. Amplicon 315 bp was present at 50, 25 and 19\% relative abundance in the Northern Florida Keys, Lee Stocking Island and Bermuda, respectively. Amplicon 316 dominated the Lee Stocking Island and US Virgin Island profiles at 45 and 22\% abundance yet represented only $5 \%$ of the community abundance in Bermuda. 
Previous studies that combined LH-PCR with cloning and sequencing to determine the phylogenetic relationships between amplicon lengths and marine seawater (Suzuki et al., 1998), coral surface mucopolysaccharide layer (SML) and BBD (Sekar et al., 2006) revealed that amplicons of lengths $313-316 \mathrm{bp}$ correspond to cyanobacteria and $\alpha$-proteobacteria. Multiple genera of cyanobacteria have been identified in association with BBD infections (Frias-Lopez et al., 2003; Myers et al., 2007) and the dominant species of cyanobacteria present in the band has been suggested to dictate the microbial composition of the BBD community (Frias-Lopez et al., 2004). It is therefore possible that regional differences observed in the BBD microbial composition are linked to the genera of cyanobacteria present locally.

None of the amplicons detected that were potentially indicative of cyanobacteria $(314,315$ or 316$)$ were present in all of the Bermuda BBD samples. Amplicons 314 and 315 were present in six samples and amplicon 316 was found in three. Two pairs of amplicons, $314 / 315$ and 314/316 were present together in two BBD samples, and all three amplicons were found together in one BBD sample. Four samples had only one representative of these amplicons, with 315 occurring in three samples and 314 present in one sample.

Comparison of the amplicon lengths that are potentially associated with cyanobacteria with amplicon lengths of cyanobacteria cultured from BBD in the wider Caribbean (Table 3) implicate that the Bermuda BBD cyanobacteria were members of the genera Geitlerinema (313 and $315 \mathrm{bp}$ ), Leptolyngbya (314 bp) and/or Oscillatoria (315 bp). Similarly, in previous work (Voss et al., 2007) analyzed the V1+V2 region 
by sequencing cultures of cyanobacteria isolated from BBD. There are discrepancies in the results of the two studies, however, in that BBD Geitlerinema 1991 had an amplicon length of 315 in the earlier study (Voss et al., 2007) and 313 in the present study, Geitlerinema strain HS-217 had an amplicon length of 313 in the earlier study and 315 in the present study, and Leptolyngbya strain FLKBBD1 had an amplicon length of 315 in the earlier study (Voss et al., 2007) and 314 in the present study. Two strains of BBD Ocillatoria, the BBD cyanobacterium most commonly found throughout the Caribbean, have a V1+V2 amplicon length of 315 bp (Table 3). Thus at most the LH-profiles presented here indicate that there were multiple strains of BBD cyanobacteria in Bermuda samples. The discrepancies in the two studies suggest that to identify the BBD microbial community members to species level will require full 16S rRNA sequencing.

Amplicons 357 and 360 were present in all nine Bermuda samples (Table 1), and represented 5 and $15 \%$ of the BBD community respectively (Figure 1). Amplicon 357 has been shown to correspond to $\delta$-proteobacteria, Firmicutes (Sekar et al., 2006) and $\gamma$ proteobacteria (Suzuki et al. 1998). Literature reports correspond amplicon 360 to Verrucomicrobia , Firmicutes (Sekar et al., 2006), $\gamma$-proteobacteria and CytophagaFlexibacter-Bacteriodes (CFB) (Suzuki et al., 1998).

Additional amplicons $(344,346,347,350,352)$ represented 2 to $10 \%$ of the community. These correspond (in literature reports) to $\gamma$-proteobacteria, $\beta$ proteobacteria, CFB, Firmicutes, and Verrucomicrobia (Suzuki et al., 1998; Sekar et al., 2006). While these bacteria are not as dominant as the cyanobacteria in BBD, it is still unknown whether populations of specific bacteria that are present in small amounts are 
crucial to BBD etiology. Recent work (Richardson et al., 2009) has shown that cyanotoxins and antimicrobial compounds produced in BBD can both promote and inhibit growth of BBD bacterial isolates. Thus the identities of the bacteria associated with amplicons representing small proportions of the community may be important as well. Many of these were present in multiple Bermuda BBD samples. For example amplicon 346 was present in six samples, 352 in eight samples, and 357 along with 360 were present in all nine samples. Thus the low proportion may not be indicative of the importance of certain bacteria to BBD.

\section{CONCLUSION}

This study represents the first molecular characterization of BBD in Bermuda. LH-PCR analysis revealed a diverse microbial community assemblage of BBD in Bermuda that is distinct from the BBD community assemblages reported in the North Florida Keys, Lee Stocking Island and the US Virgin Islands. Several amplicons were found specific to BBD infections in Bermuda and many amplicons absent in Bermuda BBD mats were reported in the other regions. Differences in the abundance of amplicons indicative of cyanobacteria were observed between each region. Multiple amplicons of lengths previously shown to correspond to BBD cyanobacteria were found in Bermuda BBD mats which supports previous work that shows more than one species of cyanobacteria may be associated with BBD infections. Certain amplicons were detected which were common to all (or most) samples analyzed, suggesting the 
presence of important specific BBD bacteria on Bermuda reefs. LH-PCR analysis is a quick method for identifying bacterial composition however future work that includes cloning and sequencing is necessary to definitively identify the organisms corresponding to the amplicons present in the BBD profiles. 


\section{ACKNOWLEDGMENTS}

I would like to thank R. Jones, J. Evered, D. Gibbs, C. Sleeter, K. Holzer for assistance at the Bermuda Institute of Ocean Sciences. I also thank D. Stanić for providing the cyanobacterial biomass for LH-PCR and J. Fetscher and B. Kallifatidis for performing the LH-PCR analysis. This work was funded by an Environmental Protection Agency Greater Research Opportunity Graduate Fellowship (MA-91697601). 


\section{REFERENCES}

Antonius, A. 1976. New observations on coral destruction in reefs. 10th Mtg Assoc of Is Mar. Lab. of Car. Abst. 3.

Boyett, H., Bourne, D.G., Willis, B., 2007. Elevated temperature and light enhance progression of black band disease on staghorn corals of the Great Barrier Reef. Mar. Biol. 151, 1711-1720.

Cooney, R.P, Pantos, O., Le Tissier, M.D., Barer, M.R., O'Donnell, A.G., Bythell, J.C., 2002. Characterization of the bacterial consortium associated with black band disease in coral using molecular microbiological techniques. Environ. Microbiol. 4, 401-413.

Edmunds, P. J., 1991. Extent and effect of black band disease on a Caribbean reef.Coral Reefs. 10, 161-165.

Frias-Lopez, J.J., Zerkle, A.L., Bonheyo, G.T., Fouke, B.W., 2002. Partitioning of bacterial communities between seawater and healthy, black band diseased, and dead coral surfaces. Appl. Environ. Microbiol. 68, 2214-2228.

Frias-Lopez J., Bonheyo, G.T., Jin, Q., Fouke, B.W., 2003. Cyanobacteria associated with coral black band disease in Caribbean and Indo-Pacific Reefs. Appl. Environ. Microbiol. 69, 2409-2413.

Frias-Lopez J., Klaus, J.S., Bonheyo, G.T., Fouke, B.W., 2004. Bacterial community associated with black band disease in corals. Appl. Environ. Microbiol. 70,5955 5962.

Garrett, P., Ducklow, H. W., 1975. Coral diseases in Bermuda. Nature 253, 349-350.

Green, E. P., Bruckner, A. W., 2000. The significance of coral disease epizootiology for coral reef conservation. Biol. Conserv. 96, 347-361.

Jones, R.J. 2005. Bermuda Institute of Ocean Sciences (BIOS), Marine Environmental Program (MEP) Annual report (2005-2006), submitted to the Bermuda Government Department of Environmental Protection, Ministry of the Environment.

Kaczmarsky, L.T., Draud, M., Williams, E.H., 2005. Is there a relationship between proximity to sewage effluent and the prevalence of coral disease? Caribb. J. Sci. $41,124-137$. 
Kuta, K. G., Richardson, L. L., 1996. Abundance and distribution of black band disease on coral reefs in the northern Florida Keys. Coral Reefs 15, 219-223.

Kuta, K. G., Richardon, L. L., 2002. Ecological aspects of black band disease of corals: relationships between disease incidence and environmental factors. Coral Reefs. $15,219-223$.

Mills, D.K., Fitzgerald, K., Litchfield, C.D., Gilleve, P.M., 2003. A comparison of DNA profiling techniques for monitoring nutrient impacts on microbial community composition during bioremediation of petroleum-contaminated soils. J. Microbiol. Methods 54, 57-74.

Myers, J.L., Sekar, R., Richardson, L.L., 2007. Molecular detection and ecological significance of the cyanobacterial genera Geitlerinema and Leptolyngbya in black band disease of corals. Appl. Environ. Microb. 73, 5173-5182.

Ramos-Flores, T., 1983. Lower marine fungus associated with black line disease in star corals (Montastrea annularis, E\&S). Biol. Bull. 165, 429-435.

Richardson, L.L., 1996. Motility patterns of Phormidium corallyticum and Beggiatoa spp. associated with black band disease of corals. Microbial. Ecol. 32,323-335.

Richardson, L. L., 1998. Coral disease what is really known? TREE. 13(11), 438-443.

Richardson, L.L., Kuta, K.G., 2003. Ecological physiology of the black band disease cyanobacterium Phormidium corallyticum. FEMS Microbiol. Ecol. 3,287 298.

Richardson, L. L., Miller, A.W., Broderick, E., Kaczmarsky, L., Gantar, M., Stanić, D., Sekar, R., 2009. Sulfide, microcystin, and the etiology of black band disease. Dis. Aquat. Org. 87, 79-90.

Rodriguez, S., Croquer, A., 2008. Dynamics of black band disease in a Diploria strigosa population subjected to annual upwelling on the northeastern coast of Venezuela. Coral Reefs. 27, 381-388.

Rützler, K., Santavy, D. L., 1983. The black band disease of Atlantic reef corals. I. Description of a cyanophyte pathogen. PSZN I: Mar. Ecol. 4, 301-319.

Rützler K, Santavy, D.L., Antonius, A., 1983. The black band disease of Atlantic reef corals. III. Distribution, Ecology and Development. PSZN I: Mar Ecol 4, 329 358. 
Sekar, R., Mills, D.K., Remily, E.R., Voss, J.D., Richardson, L.L., 2006. Microbial communities in the surface mucopolysaccharide layer and the black band microbial mat of black band-diseased Siderastrea siderea. Appl. Environ. Microbiol. 72, 5963-73.

Sutherland, K.P., Porter, J.W., Torres, C., 2004. Disease and immunity in Caribbean and Indo-Pacific zooxanthellate corals. Mar. Ecol. Prog. Ser. 266, 273-302.

Suzuki, M., Rappe, M.S., Giovannoni, S.J., 1998. Kinetic bias in estimates of coastal picoplankton community structure obtained by measurements of small-subunit rRNA gene PCR amplicon length heterogeneity. Appl. Environ. Microbiol. 64, 4522-4529.

Viehman, S., Mills D.K., Meichel, G.W., Richardson, L.L., 2006. Culture and identification of Desulfovibrio spp. from corals infected by black band disease on Dominican and Florida Keys reefs. Dis. Aquat. Organ. 69(1), 119-27.

Voss, J., Richardson, L.L, 2006. Nutrient enrichment enhances black band disease progression in corals. Coral Reefs. 25, 569-576.

Voss, J.D., Mills, D.K., Myers, J.L., Remily, E.R., Richardson, L.L. 2007. Black band disease microbial community variation on corals in three regions of the wider Caribbean. Microb. Ecol. 54, 730-739.

Ward, J.R., Lafferty, K.D., 2004. The elusive baseline of marine disease: are diseases in ocean ecosystems increasing? PLoS Biol 2: E120.

Weil, E., Smith, G., Gil-Agudelo, D.L., 2006. Status and progress in coral reef disease research. Dis. Aquat. Organ. 69, 1-7. 
Table 1. Amplicons associated with one or more BBD samples in Bermuda.

\begin{tabular}{cccccccc}
\hline Number of Samples & $\mathbf{1}$ & $\mathbf{2}$ & $\mathbf{3}$ & $\mathbf{5}$ & $\mathbf{6}$ & $\mathbf{8}$ & $\mathbf{9}$ \\
\hline \multirow{2}{*}{$\begin{array}{c}\text { Amplicon Lengths } \\
\text { (bp) }\end{array}$} & & $304,323,350$ & 316,326, & 344 & 314,315, & 352 & 357,360 \\
& & 339,340, & & 334,346, & \\
& & 341,347, & & & \\
\end{tabular}

Table 2. Amplicons in BBD samples specific to Bermuda, absent in Bermuda, and common to Bermuda and other Caribbean regions.

\begin{tabular}{|c|c|c|c|c|c|}
\hline & $\begin{array}{l}\text { Specific to } \\
\text { Bermuda }\end{array}$ & $\begin{array}{l}\text { Absent in } \\
\text { Bermuda }\end{array}$ & $\begin{array}{c}\text { Bermuda: } \\
\text { NFK }\end{array}$ & $\begin{array}{c}\text { Bermuda: } \\
\text { LSI }\end{array}$ & $\begin{array}{c}\text { Bermuda: } \\
\text { USVI }\end{array}$ \\
\hline Amplicon Length (bp) & $\begin{array}{c}302,323,326 \\
334,339,347,357\end{array}$ & $\begin{array}{c}306,313,322,328 \\
329,336,343,345 \\
348,353,355,356, \\
358,359\end{array}$ & $\begin{array}{c}304,315,341 \\
344,346,350 \\
360\end{array}$ & $\begin{array}{l}304,315, \\
316,341 \\
346,350\end{array}$ & $\begin{array}{l}314,316,340, \\
349,350,352\end{array}$ \\
\hline
\end{tabular}

Table 3. Amplicon lengths of cyanobacteria cultured from BBD in the wider Caribbean.

\begin{tabular}{cccc}
\hline Sample & Genus & $\begin{array}{c}\text { Amplicon length } \\
\text { (bp) }\end{array}$ & Location \\
\hline BBD 1991 & Geitlerinema & 313 & Florida Keys \\
HS 217 & Geitlerinema & 315 & Bahamas \\
W-1 & Geitlerinema & 313 & Florida Keys \\
FLK BBD1 & Leptolyngbya & 314 & Florida Keys \\
102d-1 & Leptolyngbya & 314 & Florida Keys \\
$100-1$ & Oscillatoria & $315^{\text {a }}$ & US Virgin Islands \\
$101-1$ & Oscillatoria & $315^{\text {a }}$ & US Virgin Islands \\
\hline
\end{tabular}

${ }^{\mathrm{a}}$ Stanić, unpublished data 




Figure 1. Mean abundance of amplicons (+SE) present in BBD sampled from nine BBD-infected colonies of D. strigosa at Whalebone Bay, Bermuda. 


\section{CHAPTER V}

\section{CONCLUSION}

Coral disease research, as reviewed by Sutherland et al. (2004), has focused on mapping the geographic distribution of disease, describing the morphological signs of disease, identifying susceptible species and characterizing the microorganisms associated with specific diseases. Several studies report increased disease prevalence with increased temperature (Rützler et al., 1983; Edmunds, 1991; Voss and Richardson, 2006; Boyett et al., 2007; Sato et al., 2009) but there is a paucity of data addressing how environmental factors affect the ability of the coral host to resist infection. Few studies have addressed disease resistance in corals, particularly the role of microbes associated with the surface mucopolysaccharide layer (SML) of healthy corals as potentially providing protection against disease (Ritchie, 2006). At present it is unknown whether epizootics occur because of more virulent pathogens, compromised host defenses, or both (Hayes and Goreau, 1998, Carey, 2000).

Determining which conditions may promote virulence and/or a weak host is

critical as epizootics are expected to increase with global warming (Epstein, 2001). The high latitude reefs of Bermuda provide an ideal and unique model system to investigate the role environmental variables, particularly temperature, play in disease progression on a susceptible and non-susceptible species. The laboratory experiment presented in chapter one was conducted to determine whether various light and temperature regimes differentially affect BBD progression on colonies of $D$. labyrinthiformis and $D$. strigosa. Colonies were artificially infected with BBD under four light and temperature 
regimes and the progression was measured and compared between species. Disease progression was slower at $26^{\circ} \mathrm{C}$ than at $30^{\circ} \mathrm{C}$ on both species at ambient light. Low light at $30^{\circ} \mathrm{C}$ resulted in reduced $\mathrm{BBD}$ progression on both species when compared to the ambient light treatment at the same temperature. High light at $30^{\circ} \mathrm{C}$ resulted in increased BBD progression on colonies on D. strigosa and reduced BBD progression on colonies of $D$. labyrinthiformis. These results suggest that light and temperature are two important environmental factors that influence BBD progression on Diploria in Bermuda. Temperature in particular, may play an important role in governing BBD progression on colonies of $D$. labyrinthiformis as the final area of BBD was significantly greater on colonies of D. labyrinthiformis in the $30^{\circ} \mathrm{C}$, ambient light treatment than on colonies of the same species in any of the other treatments. These results, while based on colonies that were artificially infected, suggest that increased temperature may reduce the ability of $D$. labyrinthiformis to resist BBD. Corroborative field studies are necessary to determine if this pattern holds in situ. Regionally cool sea surface temperatures in Bermuda typically do not exceed $28^{\circ} \mathrm{C}$ (Cook, 1990). On the lower latitude reefs of the wider Caribbean, however, surface temperatures are typically reach or exceed $30^{\circ} \mathrm{C}$. Therefore regionally cooler water in Bermuda may contribute to the extremely low BBD prevalence among D. labyrinthiformis.

Other factors aside from prevailing temperature and light conditions in Bermuda likely influence the low BBD prevalence among D. labyrinthiformis. Microbes present in the SML may offer protection against disease. In chapter two, the bacterial communities present in the in the SML of healthy corals and in the healthy areas of 
BBD infected colonies of D. labyrinthiformis and D. strigosa were characterized. The SML was collected from colonies located at two reef locations, a northern rim reef with minimal human impact and an inshore patch reef close to potential anthropogenic stressors. Results indicated that bacterial communities differed between healthy and BBD-infected corals, suggesting a shift in the normal bacterial community either prior to the onset of disease or as a result of the disease. Analysis of bacterial community profiles from the SML of healthy colonies collected at both sites showed that at SML sampled from the same reef site, regardless of coral species were similar while those between sites were significantly different. In other words, location rather than host species seems to be driving the microbial diversity in the SML. The bacterial profiles of both $D$. labyrinthiformis and $D$. strigosa were dominated by amplicons of the same lengths and relative abundances, which suggests that the observed difference in BBD prevalence between these two species may be attributed to factors other than the microbial communities present within the SML. Unique amplicons were associated with each species and there may be specific bacteria in the SML that play a role in susceptibility to BBD.

The bacterial composition of BBD has previously been shown to be location, rather than species dependant (Voss et al., 2007). Therefore, the goal of chapter three was to profile the bacterial composition of BBD in Bermuda using LH-PCR and compare it to previously published LH-PCR BBD profiles from samples collected from the Bahamas, U.S. Virgin Islands, and the Florida Keys. Analysis of the community profiles revealed that the bacterial community composition of BBD in Bermuda is 
distinct from the other regions sampled. Multiple amplicons present in the Caribbean BBD samples were absent in Bermuda BBD samples, several amplicons were unique to BBD in Bermuda, and amplicons that were shared between regions were present in different abundances. Multiple amplicons of lengths previously shown to correspond to BBD cyanobacteria were found in Bermuda BBD mats which supports previous work that shows more than one species of cyanobacteria may be associated with BBD infections (Frias-Lopez et al., 2003; Myers et al., 2007). Certain amplicons were detected which were common to all (or most) samples analyzed, suggesting the presence of important specific BBD bacteria on Bermuda reefs. The LH-PCR analysis is a quick method for identifying bacterial composition however future work that includes cloning and sequencing is necessary to definitively identify the organisms corresponding to the amplicons present in the BBD profiles.

The cumulative results from this thesis reveal that several factors are likely responsible for the difference in BBD prevalence between $D$. labyrinthiformis and $D$. strigosa in Bermuda. Prevailing temperature and light conditions may act as a foundation for further investigations to explain the differences in observed BBD infections between these two species in Bermuda. Other factors such as the unique coral-associated microbes present in the SML of each species may influence disease susceptibility, particularly at locations potentially impacted by anthropogenic sources. The composition of the bacteria present in the BBD microbial mat in Bermuda is distinct from that of other regions of the Caribbean where D. labyrinthiformis has been reported to be infected with BBD. Cloning and sequencing is necessary to determine 
the identity of bacteria within the band and may further elucidate the reasons behind the unique pattern of BBD infections in Bermuda. Studies such as this that have examined factors such as prevailing environmental conditions, geographic location and host microbial assemblages are key to understanding coral disease resistance. 


\section{REFERENCES}

Boyett, H., Bourne, D.G., Willis, B., 2007. Elevated temperature and light enhance progression of black band disease on staghorn corals of the Great Barrier Reef. Mar. Biol. 151,1711-1720.

Carey, C. 2000. Infectious disease and worldwide declines of amphibian populations, with comments on emerging diseases in coral reef organisms and in humans. Environ. Health . 108 Suppl 1, 143-150.

Cook, C.B., Logan, A., Ward, J., Luckhurst, B., Berg, C.J., 1990. Elevated temperatures and bleaching on a high latitude coral reef: the 1988 Bermuda event. Coral Reefs 9, 45-49.

Edmunds, P.J., 1991. Extent and effect of black band disease on a Caribbean reef. Coral Reefs 10,161-165.

Epstein, P.R., 2001. Climate change and emerging infectious diseases. Microbes Infect. 3:747-754.

Frias-Lopez J., Bonheyo, G.T., Jin, Q., Fouke, B.W., 2003. Cyanobacteria associated with coral black band disease in Caribbean and Indo-Pacific Reefs. Appl. Environ. Microbiol. 69, 2409-2413.

Hayes, R.L., Goreau, T.J., 1998. The significance of emerging diseases in the tropical coral reef ecosystem. Rev. Biol. Trop. 46,173-185.

Myers, J.L., Sekar, R., Richardson, L.L., 2007. Molecular detection and ecological significance of the cyanobacterial genera Geitlerinema and Leptolyngbya in black band disease of corals. Appl. Environ. Microb. 73, 5173-5182.

Ritchie, KB (2006) Regulation of microbial populations by coral surface mucus and mucus-associated bacteria. Mar Ecol Prog Ser 322: 1-14.

Rützler, K., Santavy, D.L., Antonius, A., 1983. The black band disease of Atlantic reef corals. III. Distribution, Ecology and Development. PSZN I: Mar Ecol 4: 329358.

Sato, Y., Bourne, D.G., Willis, B.L., 2009. Dynamics of seasonal outbreaks of black band disease in an assemblage of Montipora species at Pelorus Island (Great Barrier Reef, Australia). Proc. R. Soc. B. 276, 2795-2803.

Sutherland, K., Porter, J.W., Torres, C., 2004. Disease and immunity in Caribbean and Indo-Pacific zooxanthellate corals. Mar. Ecol. Prog. Ser. 266, 273-302. 
Voss, J.D., Richardson, L.L., 2006. Coral diseases near Lee Stocking Island, Bahamas: patterns and potential drivers. Dis. Aquat. Organ. 69:33-40.

Voss, J.D., Mills, D.K., Myers, J.L., Remily, E.R., Richardson, L.L., 2007. Black band disease microbial community variation on corals in three regions of the wider Caribbean. Microb. Ecol. 54, 730-739. 


\section{APPENDIX A}

\section{DNA extraction}

SML $(500 \mu 1)$ was placed directly into Multimix lysing matrix tubes (BIO 101 Systems, Q-Biogene, California) and bead beaten for three minutes using a Genie 2 vortex (Fisher Scientific, Pittsburgh, PA). The DNA was eluted once in $50 \mu 1$ of sterile nuclease free-water (heated to $65^{\circ} \mathrm{C}$ ) and verified using Tris-borate-EDTA (TBE) agarose gels $(1 \% \mathrm{wt} / \mathrm{vol})$ stained with ethidium bromide. DNA was quantified using a Bio-Rad VersaFlour ${ }^{\mathrm{TM}}$ fluorometer (Richmond, CA, USA) and subsequently diluted with sterile nuclease-free water to a concentration of $10 \mathrm{ng} / \mu \mathrm{l}$. Sub-samples (11 of 50 samples) were extracted in duplicate to confirm that the DNA extraction method resulted in reproducible LH-PCR profiles as previously reported [12, 31].

\section{Amplicon-length heterogeneity (LH) PCR}

The final concentrations of reagents used in the PCR reactions were: 1x PCR buffer, $2.5 \mathrm{mM} \mathrm{MgCl}_{2}, 0.25 \mathrm{mM}$ of each deoxynucleoside triphosphate (Promega, Madison, WI), $0.5 \mu \mathrm{M}$ forward and reverse primer, 0.5 U AmpliTaq Gold DNA polymerase (Applied Biosystems, Foster City, CA), 0.1\% (wt/vol) bovine serum albumin (fraction V; Fisher, Suwannee, GA), 10 ng of genomic DNA, and nuclease-free water, for a final volume of $20 \mu 1$ [25,31]. DNA from Escherichia coli was amplified for a positive control and nuclease-free water was used as a negative control. PCR reactions were conducted in a Peltier Thermal Cycler (PTC-200, MJ Research, Waltham, MA) with an initial denaturing step at $95^{\circ} \mathrm{C}$ for $5 \mathrm{~min}$, followed by 30 cycles of $95^{\circ} \mathrm{C}$ for $1 \mathrm{~min}, 55^{\circ} \mathrm{C}$ for $1 \mathrm{~min}, 72^{\circ} \mathrm{C}$ for $1 \mathrm{~min}$, with a final extension step at $72^{\circ} \mathrm{C}$ 
for 10 min. PCR products were verified using 1\% TBE agarose gels along with a $100 \mathrm{bp}$ DNA ladder (Promega, Madison, WI) and 5x loading dye (Qiagen, Valencia, CA). PCR reactions were carried out in triplicate for each replicate DNA extract.

Each sample $(0.5 \mu 1$ PCR product $)$ was denatured with $9.5 \mu 1$ of $96: 1 \mathrm{Hi}_{-} \mathrm{Dye} \mathrm{T}^{\mathrm{TM}}$ deionized formamide to GeneScan ${ }^{\circledR}$ ROX 500 internal standard solution (Applied Biosystems (ABI), Foster City, CA, USA) and separated by size on a capillary electrophoresis ABI 310 DNA genetic analyzer using polymer POP-4, matrix DS30_6FAM_HEX_NED_ROX and filter D. The electropherograms (profiles) from each sample were analyzed using ABI's Prism GeneMapper ${ }^{\circledR}$ version 4.0 software. Analysis was limited to amplicons between 300 and 400 base pair (bp) in length. Size (bp) and relative abundance (fluorescence) of each amplicon were measured using the Local Southern (Size Calling) Method with no peak correction or smoothing. The community profiles, which consist of the size and abundance of each amplicon present in a sample, were imported into Microsoft Excel (Microsoft, Redmond, Washington). An amplicon was only included in the analysis if it occurred in at least two of the three replicate PCR reactions. Amplicons were removed from the analysis if they comprised less than $1.0 \%$ of the total relative abundance and abundance data were averaged among replicates. 